\title{
Diel and seasonal changes of biogenic volatile organic compounds within and above an Amazonian rainforest
}

\author{
A. M. Yáñez-Serrano ${ }^{1,3}$, A. C. Nölscher ${ }^{2}$, J. Williams ${ }^{2}$, S. Wolff ${ }^{1,3}$, E. Alves ${ }^{3}$, G. A. Martins ${ }^{3}$, E. Bourtsoukidis ${ }^{2}$, \\ J. Brito ${ }^{4}$, K. Jardine ${ }^{3,5}$, P. Artaxo ${ }^{4}$, and J. Kesselmeier ${ }^{1}$ \\ ${ }^{1}$ Biogeochemistry Department, Max Planck Institute for Chemistry, P. O. Box 3060, 55020 Mainz, Germany \\ ${ }^{2}$ Atmospheric Chemistry Department, Max Planck Institute for Chemistry, P. O. Box 3060, 55020 Mainz, Germany \\ ${ }^{3}$ Instituto Nacional de Pesquisas da Amazônia (INPA), Av. André Araújo 2936, Manaus-AM, CEP 69083-000, Manaus, Brasil \\ ${ }^{4}$ Instituto de Física, Universidade de São Paulo (USP), Rua do Matão, Travessa R, 187, CEP 05508-900, São Paulo, SP, Brasil \\ ${ }^{5}$ Lawrence Berkeley National Laboratory (LBNL), Earth Science Division, One Cyclotron Rd, building 64-241, Berkeley, \\ CA 94720, USA
}

Correspondence to: A. M. Yáñez-Serrano (ayanezserrano@mpic.de)

Received: 24 October 2014 - Published in Atmos. Chem. Phys. Discuss.: 24 November 2014

Revised: 26 February 2015 - Accepted: 4 March 2015 - Published: 25 March 2015

\begin{abstract}
The Amazonian rainforest is a large tropical ecosystem, which is one of the last pristine continental terrains. This ecosystem is ideally located for the study of diel and seasonal behaviour of biogenic volatile organic compounds (BVOCs) in the absence of local human interference. In this study, we report the first atmospheric BVOC measurements at the Amazonian Tall Tower Observatory (ATTO) site, located in central Amazonia. A quadrupole proton-transfer-reaction mass spectrometer (PTR-MS), with seven ambient air inlets, positioned from near ground to about $80 \mathrm{~m}(0.05,0.5,4,24,38,53$ and $79 \mathrm{~m}$ above the forest floor), was deployed for BVOC monitoring. We report diel and seasonal (February-March 2013 as wet season and September 2013 as dry season) ambient mixing ratios for isoprene, monoterpenes, isoprene oxidation products, acetaldehyde, acetone, methyl ethyl ketone (MEK), methanol and acetonitrile. Clear diel and seasonal patterns were observed for all compounds. In general, lower mixing ratios were observed during night, while maximum mixing ratios were observed during the wet season (February-March 2013), with the peak in solar irradiation at 12:00 LT (local time) and during the dry season (September 2013) with the peak in temperature at 16:00 LT. Isoprene and monoterpene mixing ratios were the highest within the canopy with a median of 7.6 and $1 \mathrm{ppb}$, respectively (interquartile range (IQR) of 6.1 and $0.38 \mathrm{ppb}$ ) during the dry season (at $24 \mathrm{~m}$, from 12:00 to 15:00 LT). The increased contribution of oxygenated volatile
\end{abstract}

organic compounds (OVOCs) above the canopy indicated a transition from dominating forest emissions during the wet season (when mixing ratios were higher than within the canopy), to a blend of biogenic emission, photochemical production and advection during the dry season when mixing ratios were higher above the canopy. Our observations suggest strong seasonal interactions between environmental (insolation, temperature) and biological (phenology) drivers of leaf BVOC emissions and atmospheric chemistry. Considerable differences in the magnitude of BVOC mixing ratios, as compared to other reports of Amazonian BVOC, demonstrate the need for long-term observations at different sites and more standardized measurement procedures, in order to better characterize the natural exchange of BVOCs between the Amazonian rainforest and the atmosphere.

\section{Introduction}

The Amazonian rainforest is one of the last pristine continental areas. Low atmospheric concentrations of nitrogen oxides $\left(\mathrm{NO}_{\mathrm{x}}\right) \leq 1 \mathrm{ppb}$ (Andreae et al., 2002; Kuhn et al., 2007) indicate little human interference. Tropospheric ozone levels of $\leq 15 \mathrm{ppb}$ for the wet season (Rummel et al., 2007) are considered natural and the influence from seasonal biomass burning can be observed during the dry season (Andreae, 2007; Kesselmeier et al., 2009; Kuhn et al., 2010; David- 
son et al., 2012; Artaxo et al., 2013). Understanding this ecosystem's interactions with the atmosphere is of vital importance to be able to predict how it will respond to future climate change. One of these ecosystem interactions is the emission of biogenic volatile organic compounds (BVOCs) by the forest, which can influence the ecosystem at different spatial scales from the cell, tissue, organism or to the whole ecosystem. At the leaf level, plants emit BVOCs as a result of signalling, thermotolerance, protection against pathogens, wound sealing and prevention against oxidative damage (Laothawornkitkul et al., 2009; Jardine et al., 2011a). In the atmosphere, BVOCs influence photochemistry and radiative forcing by the formation of secondary oxidants (such as tropospheric ozone) and by contributing to the secondary organic aerosol (SOA) budget (Kesselmeier et al., 2002b; Williams, 2004; Artaxo et al., 2009). In the Amazonian rainforest, the high amount of total above ground biomass of $93 \pm 23 \mathrm{Pg} \mathrm{C}$ (Malhi et al., 2006), the high yearround temperatures $\left(24-26^{\circ} \mathrm{C}\right.$ mean; Nobre et al., 2009), the high insolation due to the equatorial geographic location $\left(33.7 \mathrm{MJ} \mathrm{J} \mathrm{m}^{-2} \mathrm{~d}^{-1}\right.$ ) and the high humidity (70\% relative humidity, annual mean) makes the atmosphere behave like a photochemical reactor, filled with reactive gases (Andreae, 2001). Thus, the atmosphere in the Amazon Basin, in terms of trace gases and aerosol composition, is strongly influenced by the biogenic emissions as well as uptake by the forest (Kesselmeier et al., 2000; Andreae et al., 2002) with significant influence on the atmospheric oxidative capacity importance (Lelieveld et al., 2008). Despite the importance of these processes for tropical atmospheric chemistry and plant physiology, it is acknowledged that field observations of BVOCs in the tropics are rare, which is likely due to logistical and technical problems including site access, power requirements, and high ambient humidity and temperatures.

\subsection{BVOC species in the Amazonian environment}

In the Amazonian rainforest, as well as on the global scale, the compound most copiously emitted by vegetation is isoprene (Crutzen et al., 2000; Karl et al., 2004; Kuhn et al., 2010), with emissions being circa 4 times the total of all anthropogenic volatile organic compounds (VOCs) (Boucher et al., 2013). Isoprene accounts for almost half of the world's biogenic emissions and its emission represents a few percent of the assimilated carbon in tropical regions (Kesselmeier et al., 2002a). Due to its high emission rates and reactivity, isoprene is a key player in the oxidative capacity of the atmosphere (Lelieveld et al., 2008). Furthermore, evidence of SOA originating from isoprene has been observed recently in several different ecosystems (Claeys et al., 2004; Paulson et al., 2009; Carlton et al., 2009; Surratt et al., 2010; Chan et al., 2010; Pye et al., 2013). Despite the expected low particulatemass yield of isoprene relative to other natural VOCs, such as monoterpenes and sesquiterpenes (Claeys et al., 2004; Surratt et al., 2010), its high abundance could potentially pro- duce enough aerosols to significantly impact radiative forcing (Hallquist et al., 2009). The seasonality of isoprene in the Amazon is well established. Atmospheric mixing ratios may vary throughout the year by a factor of 4 (Kesselmeier et al., 2002b). During the wet season, the emission of isoprene is much lower, due to reduced sunshine from cloud cover and slightly lower temperatures compared to the dry season, when high temperatures and radiation stimulate stronger biogenic emissions. In addition, strong seasonal cycles of vegetation growth and growth development, as observed by dendrochronology as well as by direct monitoring of emission quality, may contribute to seasonal isoprene fluctuations (Kuhn et al., 2004a, b; Kesselmeier et al., 2009).

Monoterpenes comprise a class of well-known isoprenoid SOA precursors (Sakulyanontvittaya et al., 2008). These compounds also influence global atmospheric chemistry due to high OH reactivity (Kesselmeier and Staudt, 1999; Atkinson and Arey, 2003). Similar to isoprene, monoterpene emissions are regulated by light and temperature (Kesselmeier and Staudt, 1999), a feature which has also been specifically demonstrated for Amazonian monoterpene emitting plant species (Kuhn et al., 2002; Jardine et al., 2015).

Oxygenated volatile organic compounds (OVOCs) are also present in the Amazonian atmosphere (Kesselmeier et al., 2002b). Their atmospheric abundance has been observed to be determined by the balance between their sources (direct plant emissions as well as secondary formation through oxidation) and sinks (reaction with oxidants and surface uptake) (Karl et al., 2009). For instance, methanol is known to have multiple sources (Folkers et al., 2008). Its biogenic origin is primarily pectin lamella in plant cell walls during periods of leaf growth, but it could also be released by plant wounding, and decomposition of soil and leaf litter (Fall and Benson, 1996). Methanol is the second, after isoprene, most highly emitted VOC in terms of carbon (Koppmann and Wildt, 2007), and its impact on atmospheric oxidation can be large, even influencing the $\mathrm{HO}_{\mathrm{x}}$ budget of the upper troposphere, especially due to its long lifetime (ca. 1 month) (Galbally and Kirstine, 2002).

Acetaldehyde has already been reported to have a 4-5fold increase from the wet to the dry season, possibly due to vegetation fires, or due to an increase of secondary biogenic sources (i.e. oxidation of other BVOC) (Kesselmeier et al., 2002b). Several biological formation mechanisms for acetaldehyde exist. During root anoxia and fermentation in plants, acetaldehyde is formed as a by-product of ethanol production and is released via the transpiration stream (Kesselmeier et al., 2009; Bracho-Nunez et al., 2012, 2013). Another source of biological production of acetaldehyde occurs during the light-to-dark transition in plants, where as an outflow mechanism, acetaldehyde is leaked from intracellular space after conversion from pyruvate (Fall, 2003; Rottenberger et al., 2004). An interesting feature is the bidirectional exchange of acetaldehyde by plants, in close relation to ambient concentrations (Rottenberger et al., 2004; Jardine 
et al., 2008). Furthermore, acetaldehyde has an important atmospheric source due to the oxidation of other BVOCs and long-lived VOCs such as ethane in the atmosphere (Seco et al., 2007).

Acetone is another very abundant oxygenated BVOC, with a variety of sources. In the troposphere, acetone is relevant due to its photolytic sink, leading to peroxyacetyl nitrate (PAN) formation under sufficient $\mathrm{NO}_{\mathrm{x}}$ levels and influencing tropospheric ozone and $\mathrm{HO}_{\mathrm{x}}$ radical concentrations (McKeen et al., 1997; Pöschl et al., 2001; Karl et al., 2002). Acetone is also emitted by vegetation. It is released after leaf wounding, with special importance for cyanogenic plant species. It is also emitted due to light-dependent and independent responses, which may be related to the decarboxylation of acetoacetate, which occurs in soil microorganisms, animals or other processes (Fall, 2003). Methyl ethyl ketone (MEK or 2-butanone) is an oxygenated BVOC which has rarely been reported (Williams et al.. 2001; Davison et al., 2008; BrachoNunez et al., 2013). Although few observations exist, MEK has been shown to be emitted from vegetation (Isidorov et al., 1985; Kirstine et al., 1998; Jardine et al., 2010; Bourtsoukidis et al., 2014). However, it is also an oxidation product butane (de Gouw et al., 2003; Bracho-Nunez et al., 2013).

Methyl vinyl ketone and methacrolein (MVK+MACR) are oxygenated compounds thought to be predominantly produced after oxidation of other VOCs, particularly, isoprene (Warneke et al., 2001; Kesselmeier et al., 2002b; Karl et al., 2009; Kuhn et al., 2010). Ambient mixing ratios of these compounds are controlled by the oxidation rate of isoprene within the atmosphere as well as potential bidirectional exchange with leaves (Jardine et al., 2013) New evidence suggests isoprene may also be oxidized within plants under stress, possibly leading to direct emission of MVK + MACR (Jardine et al., 2011a). Moreover, there is increasing evidence of an isoprene hydroperoxide dominated chemistry under low $\mathrm{NO}_{\mathrm{x}}$ conditions, such as in the Amazon. Thus, hydroperoxides must be considered a major isoprene oxidation products in these environments (Liu et al., 2013; Rivera-Rios et al., 2014).

Although acetonitrile is generally considered a biomass burning tracer (Lobert et al., 1990; Andreae and Merlet, 2001), it has also been reported to be emitted by plants (Nyalala et al., 2011, 2013) and soils (Bange and Williams, 2000). Nonetheless, it is widely considered an anthropogenic VOC given that most regional biomass burning events are man-made (Crutzen and Andreae, 1990) and the importance of biogenic sources is unknown. Its long atmospheric lifetime with respect to $\mathrm{OH}$ oxidation (2-3 years) allows for long-range transport (Williams et al., 2001).

\subsection{Objectives}

The objective of this study is to provide a detailed description of BVOC mixing ratios in and above the canopy and their diurnal fluctuations, which can indicate heterogeneous sources and sinks within the canopy, and can be related to the exchange between the Amazonian forest and the atmosphere under dry and wet seasonal conditions. Measurements were performed on an $80 \mathrm{~m}$ tower at the site of the Amazonian Tall Tower Observatory (ATTO), and therefore represent a new data set from this very pristine area. Several (two) field campaigns enabled the determination of seasonal, diel, and vertical variation of BVOCs. This new information allows for a more comprehensive understanding of BVOC emissions and interactions within the central Amazon rainforest.

\section{Methodology}

\subsection{Site description}

The ATTO site is located in central Amazonia, $135 \mathrm{~km}$ northeast from Manaus, the closest populated area. The reserve in which ATTO is embedded comprises 424430 hectares of mainly non-flooded closed forest vegetation (terra firme), but also black-water floodplain forests (igapó), old non-flooded alluvial terraces (paleoigapó) and open-forest vegetation on white sands (campina). The main wind direction at the site is north-east and therefore most of the air masses arriving at the site, have passed through $1500 \mathrm{~km}$ of undisturbed terra firme rainforest, with negligible intrusion of air masses from Manaus. This unique situation makes this site very suitable for long-term measurements of biosphere-atmosphere exchange in the Amazon region. The site, with a mean canopy height of $35 \mathrm{~m}$, is equipped with an $80 \mathrm{~m}$ walk-up tower (INSTANT tower; $02^{\circ} 08^{\prime} 38.8^{\prime \prime} \mathrm{S}, 58^{\circ} 59^{\prime} 59.5^{\prime \prime} \mathrm{W}$ ). Measurements cover several research areas such as meteorology, micrometeorology, phenology, dendrochronology, hydrology and atmospheric chemistry/physics and are performed continuously for gases such as $\mathrm{O}_{3}, \mathrm{NO}, \mathrm{NO}_{2}, \mathrm{CO}_{2}, \mathrm{CO}, \mathrm{CH}_{4}$ and $\mathrm{H}_{2} \mathrm{O}$ as well as aerosol particle size, number and composition. These studies were complemented by the periodic determination of total $\mathrm{OH}$ reactivity and VOC levels during intensive field measurement campaigns.

\subsubsection{Measurement period}

This site generally experiences dry seasonal conditions from August to October, during which cumulative precipitation is less than $100 \mathrm{~mm} \mathrm{month}^{-1}$ (Restrepo-Coupe et al., 2013). During the wet season, it reaches values of $350 \mathrm{~mm} \mathrm{month}^{-1}$ where solar radiation is lower due to higher cloud cover (Araujo et al., 2002; Pauliquevis et al., 2012). We measured during two different campaigns, which represent the two extremes of seasonality (see information about seasonality analysis in Sect. 3.2). The wet season campaign took place from 20 February to 6 March 2013. The dry season campaign took place from 20 to 30 September 2013. 
Table 1. Compounds calibrated for PTR-MS measurements with respective protonated mass-to-charge $(\mathrm{m} / \mathrm{z})$, PTR-MS dwell time and detection limit (LOD) for the wet and the dry season. In addition, the calibration factors (ncps ppb ${ }^{-1}$ ) obtained are reported for the wet and dry season. Lastly, total PTR-MS uncertainty for both seasons is shown.

\begin{tabular}{|c|c|c|c|c|c|c|c|}
\hline$m / z$ & Compound & $\begin{array}{l}\text { Dwell } \\
\text { time }\end{array}$ & $\begin{array}{l}\text { LOD wet } \\
\text { season (ppb) }\end{array}$ & $\begin{array}{l}\text { LOD dry } \\
\text { season (ppb) }\end{array}$ & $\begin{array}{l}\text { Calibration factor wet } \\
\text { season }(\mathrm{ncps} \mathrm{ppb}-1)\end{array}$ & $\begin{array}{l}\text { Calibration factor dry } \\
\text { season }\left(\mathrm{ncps} \mathrm{ppb}^{-1}\right)\end{array}$ & $\begin{array}{l}\text { Mean total } \\
\text { uncertainty } \%\end{array}$ \\
\hline 33 & Methanol & $200 \mathrm{~ms}$ & 1.7 & 1.15 & 10.73 & 9.08 & 37.7 \\
\hline 42 & Acetonitrile & $1 \mathrm{~s}$ & 0.04 & 0.01 & 22.82 & 18.1 & 15.2 \\
\hline 45 & Acetaldehyde & $1 \mathrm{~s}$ & 0.28 & 0.17 & 21.71 & 16.3 & 16.5 \\
\hline 59 & Acetone & $1 \mathrm{~s}$ & 0.13 & 0.07 & 22.69 & 17.38 & 6.2 \\
\hline 69 & Isoprene & $1 \mathrm{~s}$ & 0.09 & 0.1 & 6.03 & 6.81 & 9.9 \\
\hline 71 & MVK+MACR & $1 \mathrm{~s}$ & 0.03 & 0.05 & 20.34 & 13.01 & 10.8 \\
\hline 73 & MEK & $1 \mathrm{~s}$ & 0.09 & 0.06 & 16.95 & 14.39 & 26.1 \\
\hline 81 & Monoterpenes & $5 \mathrm{~s}$ & 0.23 & 0.05 & 4.98 & 4.05 & 10.4 \\
\hline
\end{tabular}

\subsection{Trace gas sampling}

Measurements of VOC mixing ratios were accompanied by the determination of total $\mathrm{OH}$ reactivity, nitric oxide $(\mathrm{NO})$, nitrogen dioxide $\left(\mathrm{NO}_{2}\right)$, ozone $\left(\mathrm{O}_{3}\right)$ and water vapour $\left(\mathrm{H}_{2} \mathrm{O}\right)$ at seven heights in and above the rainforest canopy. The lower part of the vertical profile $(0.05,0.5$ and $4 \mathrm{~m}$ above the forest floor) was set up in undisturbed vegetation adjacent to the INSTANT tower (distance $12 \mathrm{~m}$ ). The upper part of the vertical profile $(24,38,53$ and $79 \mathrm{~m}$ above the forest floor) was mounted on the north-west corner of the INSTANT tower. Seven Teflon tubes (OD 3/8 in.) of different lengths were guided to a valve system switching every $2 \mathrm{~min}$ between the different heights, completing a whole profile in 16 min. Trace gas loss within the tubing was checked by injecting calibration gas at a known concentration at the different inlet heights. No significant difference between the different line lengths was found, and the average loss for each compound was within proton-transfer-reaction mass spectrometer (PTR-MS) measurement uncertainty $(\approx 10 \%)$ (Table 1$)$. Thus, we regard line losses as negligible. While a line was not being sampled, it was kept flushed by a by-pass pump. Using a Teflon pump and a flow rate of $16 \mathrm{lpm}$, the residence times were $24,17,13,9,4,5$ and $5 \mathrm{~s}$ for 79, 53, 38, 24, 4, 0.5 and $0.05 \mathrm{~m}$, respectively. Heated $\left(50^{\circ} \mathrm{C}\right)$ and insulated transfer lines (polytetrafluoroethylene, PTFE) were connected to a PTR-MS, which was housed in an air conditioned lab container $10 \mathrm{~m}$ from the INSTANT tower (see Fig. 1).

\subsection{Proton-transfer-reaction mass spectrometry}

Measurements of VOCs were performed using a PTR-MS (Ionicon Analytic GmbH, Austria) operated under standard conditions (2.2 mbar drift pressure, $600 \mathrm{~V}$ drift voltage, $127 \mathrm{Td}$ ) (Lindinger et al., 1998). Each level of the vertical profile was sampled for 2 min with six to seven cycles (ca. $20 \mathrm{~s}$ each) of PTR-MS measurements. A catalytic converter (Supelco, Inc. with platinum pellets heated to $>400^{\circ} \mathrm{C}$ ) was used to convert ambient VOC to $\mathrm{CO}_{2}+\mathrm{H}_{2} \mathrm{O}$ to determine the background signal for each compound once every hour. Background values were interpolated over the time of the measurements. Detection limits (LOD) were calculated as $2 \sigma$ of the background averages (Kaser et al., 2013) (Table 1).

Humidity dependent calibrations (using bubbled synthetic zero air to dilute the standard, regulated as close as possible to ambient humidity conditions) were performed using a gravimetrically prepared multicomponent standard, including methanol $(\mathrm{m} / \mathrm{z} 33)$, acetonitrile $(\mathrm{m} / \mathrm{z} 42)$, acetaldehyde $(\mathrm{m} / \mathrm{z} 45)$, acetone $(\mathrm{m} / \mathrm{z} 59)$, isoprene $(\mathrm{m} / \mathrm{z} 69)$, MVK + MACR $(m / z, 71), \operatorname{MEK}(m / z ~ 73)$ and $\alpha$-pinene $(\mathrm{m} / \mathrm{z}, 137$ and $\mathrm{m} / \mathrm{z}$ 81) with dilution steps ranging from 22 to $0.8 \mathrm{ppb}$ (Table 1) (Ionicon, Austria, for the wet season and Apel and Riemer for the dry season). In order to improve sensitivity, monoterpenes were quantified using $\mathrm{m} / \mathrm{z}$ 81, which was positively correlated with $\mathrm{m} / z 137$ (Pearson coefficient for $m / z 81$ against $m / z$ 137: 0.71 ). This approach has been used previously to improve LOD and sensitivity due in part to higher quadrupole transmission of $m / z, 81$ compared with the parent ion $\mathrm{m} / \mathrm{z} 137$ (Tani et al., 2003; Rinne et al., 2005; Misztal et al., 2011). We rule out a large interference of other compounds other than monoterpene fragments on $m / z, 81$ due to the fact that the observed mixing ratios are similar to those observed in other studies (Rinne et al., 2002; Jardine et al., $2011 \mathrm{~b}$ ), and the $1: 10$ ratio between isoprene and monoterpene mixing ratios has been previously reported in Rondônia (Kesselmeier et al., 2002b).

The PTR-MS technology allows for fast sampling at very low mixing ratios, but the system relies solely on mass-overcharge ratios $(\mathrm{m} / \mathrm{z})$ for compound specification. To crossvalidate compounds, gas chromatography was performed for isoprene and monoterpenes ( $\alpha$-pinene, camphene, 1 octen-3-ol, sabinene, $\beta$-pinene, myrcene, $\alpha$-phellandrene, 3 carene, $\alpha$-terpinene, $\rho$-cymene, limonene and $\delta$-terpinene) using a gas chromatography-flame ionization detector (GCFID). On chosen days, 3.3 L samples were collected continuously at selected heights using a GSA SG-10-2 personal sampler pump. Ambient air was drawn through absorbent filled tubes - carbograph 1, carbograph $5130 \mathrm{mg}$ of Carbo- 


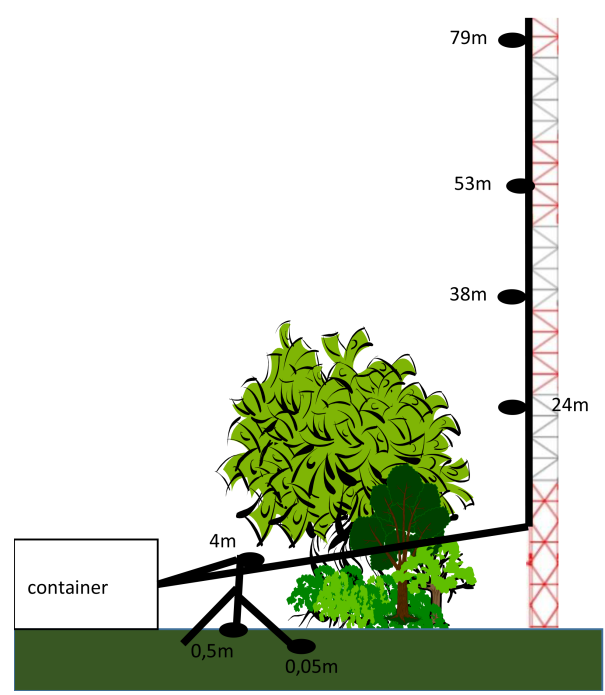

Figure 1. Schematic diagram of the experimental inlet set-up. The various inlet heights at the tower and tripod are shown with respect to the canopy. The PTR-MS was housed in the air conditioned measurement container.

graph $1\left(90 \mathrm{~m}^{2} \mathrm{~g}^{-1}\right)$ followed by $130 \mathrm{mg}$ of Carbograph 5 $\left(560 \mathrm{~m}^{2} \mathrm{~g}^{-1}\right)$. The size of the Carbograph particles was in the range of 20-40 mesh. Carbographs 1 and 5 were provided by L.A.R.A s.r.l. (Rome, Italy) (Kesselmeier et al., 2002b). Sorbent tubes for thermal desorption were analyzed by GC-FID in the laboratory in order to validate the measurements by the PTR-MS. The analytical uncertainty of the measurements by GC-FID was less than $10 \%$ (Kesselmeier et al., 1997). In addition, decomposition of some monoterpene species cannot be totally ruled out during the transport from the forest to the laboratory. Therefore, losses to adsorbent, in particular the decomposition of some monoterpene species, due to storage time between sampling and analysis cannot be totally ruled out. Thus, the sampling errors were determined to be less than $20 \%$. The total uncertainty of the PTR-MS determination was calculated according to the error propagation method (Doerffel, 1984) taking into account the uncertainty of the calibration (including multicomponent gas standard and mass flow controllers errors), the PTR-MS itself and the background error. These uncertainties for the PTR-MS measurements can be observed in Table 1. Not all compounds could be cross-validated by GC-FID. For PTRMS detected masses such as $m / z, 33, \mathrm{~m} / \mathrm{z}, 42, \mathrm{~m} / \mathrm{z} 45, \mathrm{~m} / \mathrm{z}, 59$, $\mathrm{m} / \mathrm{z} 71$ and $\mathrm{m} / \mathrm{z}, 73$, we relied on an identification which has been generally agreed on by reasonable exclusion of some species (Williams et al., 2001; Warneke et al., 2003; de Gouw and Warneke, 2007). It should be noted that recent research has shown the possibility of isoprene hydroperoxy radicals (ISOPOOH) which could interfere in $m / z 71$, especially under low $\mathrm{NO}_{\mathrm{x}}$ conditions, in which isoprene hydroperoxides are the dominant first-generation oxidation products from isoprene. Therefore, $m / z 71$ within this study should be con- sidered as MVK+MACR+ISOPOOH even though it was only calibrated for MVK+MACR (Liu et al., 2013; RiveraRios et al., 2014).

Similarly, there could be multiple contributors to the mass for $m / z$ 73. It has been reported that MEK represents $74 \%$ of this signal in most air masses (Karl et al., 2007; Warneke et al., 2003). The most likely other contributors to this $\mathrm{m} / \mathrm{z}$ would be butanal, methyl glyoxal and acrylic acid. However, acrylic acid and methyl glyoxal would not have been able to make it through the $12-90 \mathrm{~m}$ length inlet lines, due to their affinity for surfaces. Furthermore, the PTR-MS technique can only measure $65 \%$ of butanal as the rest fragments to $\mathrm{m} / \mathrm{z} 55$ compared to the MEK which is detected in $100 \%$ at $\mathrm{m} / \mathrm{z} 73$ (Lindinger et al., 1998). A possible interference from water clusters on the MEK signal was tested by calculating correlations between water and MEK. A poor correlation $(r<0.5)$ was observed, suggesting the absence of interfering water clusters in $m / z$ 73. Methyl glyoxal is a compound which results from isoprene oxidation, and therefore it closely follows the isoprene and isoprene oxidation product patterns. MEK mixing ratios did not change significantly in magnitude for the wet to the dry season, but only in patterns, whereas isoprene differed between seasons by a factor of 4 and the isoprene oxidation products differed by a factor of 10 (Sects. 3.3 and 3.5). Therefore, methyl glyoxal could also be eliminated as a contributor. Furthermore, in this special case, the pattern obtained was consistent with the stability and relatively long lifetime of MEK (5.4 days), since mixing ratios remained relatively constant higher up in the canopy and above the canopy (Grant et al., 2008; Williams et al., 2001). Thus, despite the possibility that contributions from other compounds to $m / z 73$ are plausible, we regard MEK as a major contributor to the signal.

\section{Results}

First, we present the cross-validation of the measurements between PTR-MS and GC-FID. Second, all measured BVOC mixing ratios are reported linking their seasonal, diel and vertical behaviour to sources, sinks and atmospheric processes. The medians were calculated from the dry (20-30 September 2013) and wet (20 February to 6 March 2013) season measurement periods. The dates expressed herein are all in local time. In all cases, variability is represented as the interquartile range (IQR) which is the $75 \%$ percentile minus the $25 \%$ percentile, thus enclosing $50 \%$ of all data.

\subsection{Cross-validation}

A cross-validation for isoprene and monoterpene data obtained by in situ PTR-MS measurements was performed offline analyzing absorbent tubes by GC-FID (Fig. 2). The temporal variation compared well. The coefficients of determination $\left(r^{2}\right)$ were 0.88 and 0.58 for isoprene and the sum 

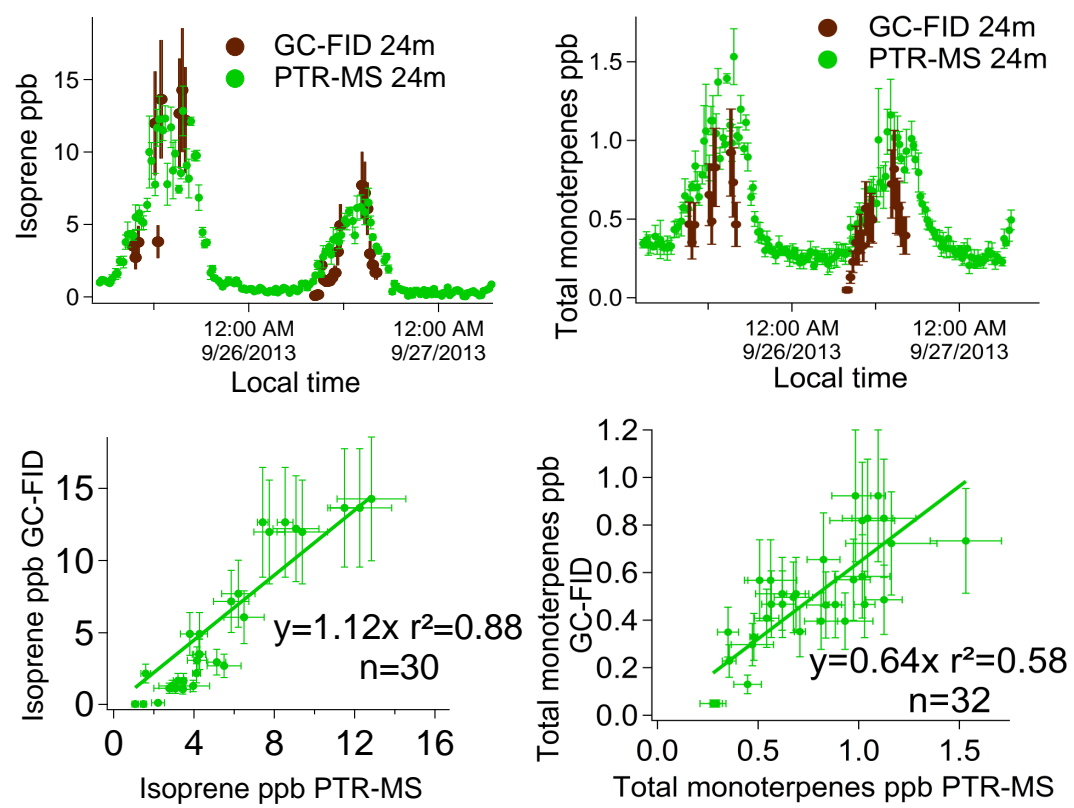

Figure 2. Top panels: example of PTR-MS and GC-FID time series data on 25 and 26 September 2013 at $24 \mathrm{~m}$ for isoprene (left) and the total monoterpenes (right). Brown points are GC-FID measurements with an error of $30 \%$ and green points are PTR-MS continuous measurements with standard deviations of the 2 min averages of the data. Bottom panel: correlation of isoprene (left) and total monoterpene (right) mixing ratios obtained by PTR-MS and GC-FID.

of monoterpenes, respectively, and a slope of $1.12(n=30)$ for isoprene and $0.64(n=32)$ for the sum of monoterpenes was calculated. The underestimation of monoterpenes (slope $<1$ ) is regarded to be a result of missing monoterpene species which could be below the detection limit for the GC-FID technique (monoterpenes detected by the GCFID technique: $\alpha$-pinene, camphene, 1-octen-3-ol, sabinene, $\beta$-pinene, myrcene, $\alpha$-phellandrene, 3 -carene, $\alpha$-terpinene, $\rho$-cymene, limonene and $\delta$-terpinene), while the PTR-MS detects the sum of all monoterpenes. Further information about uncertainty can be found in Sect. 2.4. For other measured masses, such as $\mathrm{m} / \mathrm{z} 33$ (methanol), $\mathrm{m} / \mathrm{z} 42$ (acetonitrile), $m / z 45$ (acetaldehyde), $m / z 59$ (acetone), $\mathrm{m} / z 71$ (MVK, MACR and ISOPOOH) and $m / z 73$ (MEK), we adopted compound identifications based on atmospheric chemistry and emission inventories reported in the literature in which acknowledgment of possible compound contribution and GC cross-checks were performed (de Gouw et al., 2003; de Gouw and Warneke, 2007; Warneke et al., 2003; Williams et al., 2001).

\subsection{Analysis of meteorological parameters}

Four campaigns were performed in the course of 1 year: in November 2012, February-March 2013, June 2013 and September 2013. The two intensive BVOC measurement periods cover the two extremes of seasonality: 20 February to 6 March 2013 (during the wet season) and 20 to 30 September 2013 (during the dry season). Meteorological conditions be- tween the dry and wet season varied significantly (Fig. 3). For September 2013, ambient temperature and net radiation measured at the tower were higher $\left(\bar{T}=26.56 \pm 2.78^{\circ} \mathrm{C}\right.$ and $\overline{Q^{*}}=147 \pm 282 \mathrm{~W} \mathrm{~m}^{-2}$ ), and rain events less frequent when compared with the February-March period $\left(\bar{T}=25.55 \pm 2.50^{\circ} \mathrm{C}\right.$ and $\left.\overline{Q^{*}}=103 \pm 220 \mathrm{~W} \mathrm{~m}^{-2}\right)$. Transition periods represented the times with mixed features from both the wet and dry seasons as observed in June, where rainfall events were quite frequent and exhibited the largest discharge of water in the whole measurement period (Fig. 3). Interestingly, temperature during the period of November 2012 further increased almost every day to a maxima of $35^{\circ} \mathrm{C}\left(\chi=28.20 \pm 3.29^{\circ} \mathrm{C}\right)$ as compared to the wet season (i.e. February-March 2013), where it barely reached $30^{\circ} \mathrm{C}$ on some days. During the dry season (i.e. September 2013) temperatures typically reached maxima of $33^{\circ} \mathrm{C}$ (maximum temperature observed for September $=36^{\circ} \mathrm{C}$ ). Of special interest is the comparison of solar radiation for November 2012 and September 2013. During the dry season more solar radiation was available at the canopy top (at noon reaching $1000 \mathrm{~W} \mathrm{~m}^{-2}$ with an overall low degree of cloud cover), whereas in November 2012 the net radiation rarely reached $800 \mathrm{~W} \mathrm{~m}^{-2}$ due to the more extended cloud cover, despite the higher temperature. More detailed information about Amazonian seasonality can be found in the literature (Araujo et al., 2002; Restrepo-Coupe et al., 2013). 

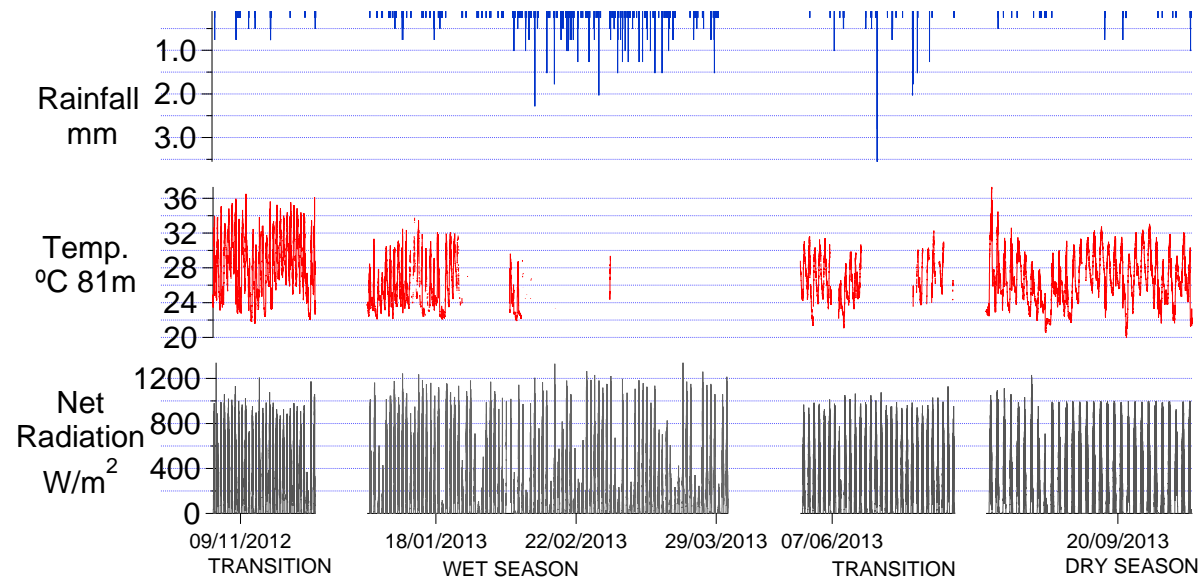

Figure 3. Meteorological data ( 2 min averages) for the intensive measurement periods at the ATTO site for the $81 \mathrm{~m}$ level of the tower reporting rainfall (blue), temperature (red) and net radiation (grey).
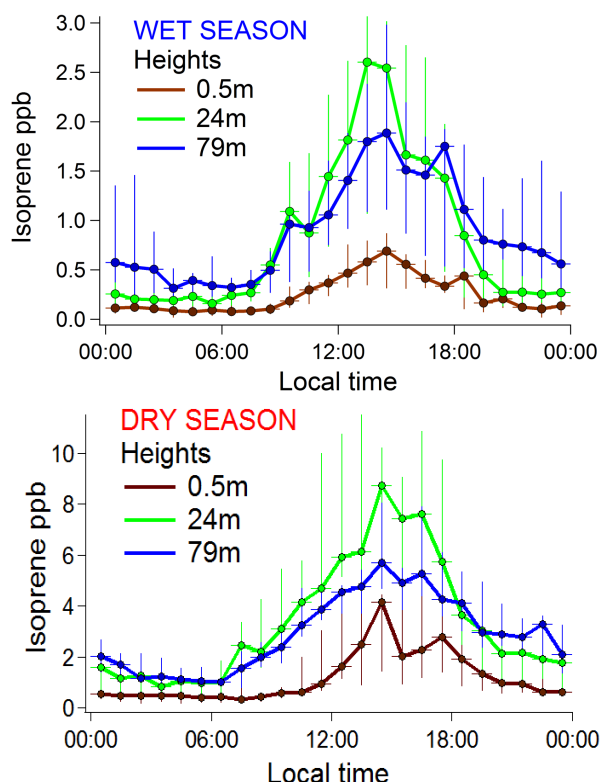

DRY SEASON

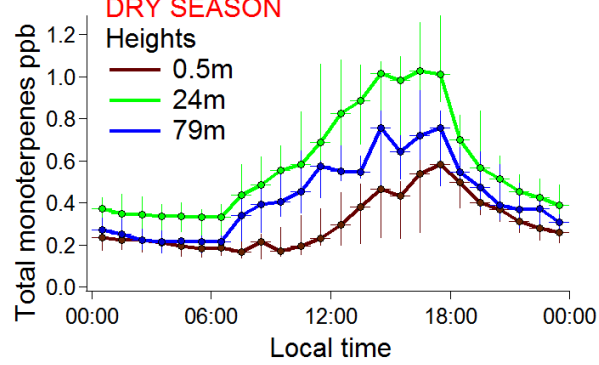

Figure 4. Diurnal hourly medians of isoprene during the wet season (top), isoprene during the dry season (middle) and the sum of monoterpenes during the dry season (bottom) (wet season data for monoterpenes are below LOD and not reported). Range bars represent the 25 and $75 \%$ percentiles.
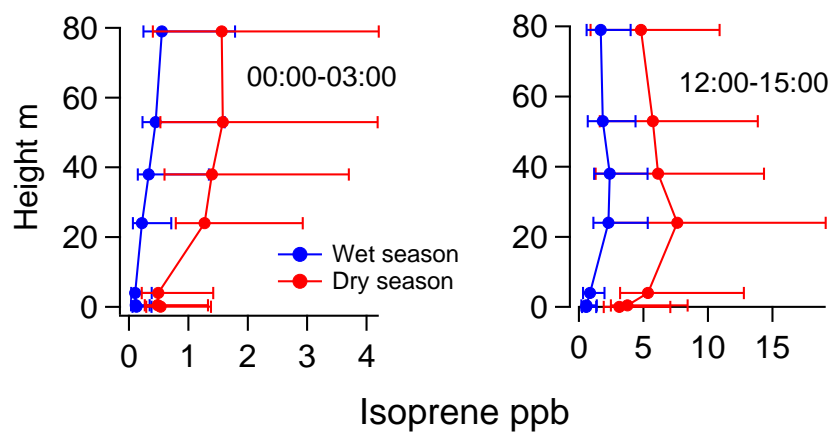

Figure 5. Vertical profiles for isoprene mixing ratios. Data are presented as medians over a period of $3 \mathrm{~h}$ between 00:00 and 03:00 LT (left) and 12:00 and 15:00 LT (right) (both local time). The $3 \mathrm{~h}$ medians are shown in red for the dry season and in blue for the wet season. Range bars represent the 25 and $75 \%$ percentiles.

\subsection{Isoprenoids}

During daytime, isoprene showed the highest mixing ratios within the canopy reaching a median of $2.29 \mathrm{ppb}$ (IQR 1.88 ) at $24 \mathrm{~m}$ for the period of 12:00-15:00 LT for the wet season and 7.6 ppb (IQR 6.1) for the same time and height during the dry season. During the night (median of the period of 00:00-03:00 LT), isoprene mixing ratios above the canopy were considerably higher than within the canopy (Fig. 4). Strong gradients towards the ground were seen, especially for the dry season, which could suggest a deposition towards the ground or plants (Fig. 5). The vertical profiles of isoprene revealed the highest mixing ratios for both day and night during the dry season. In addition, its variability increased during the dry season compared to the wet season, as observed in the difference of IQR of $1.9 \mathrm{ppb}$ during the wet season to $6.1 \mathrm{ppb}$ during the dry season, at $24 \mathrm{~m}$ for the period 12:00 15:00 LT. The vertical profiles for isoprene during the wet season had a relatively stronger night-to-day variability at 

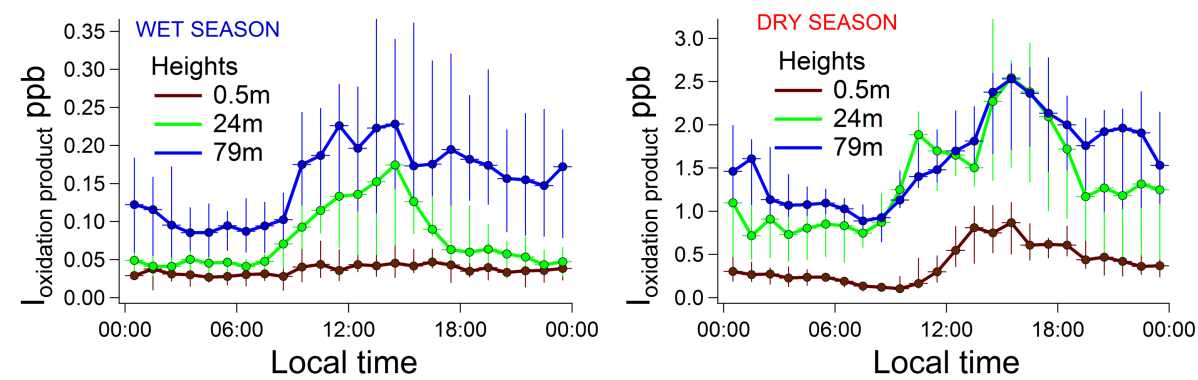

Figure 6. Diurnal hourly median isoprene oxidation product ( $\mathrm{I}_{\text {oxidation products }}$ ) mixing ratios during the wet season (left) and the dry season (right) for different heights. Range bars represent the 75 and the $25 \%$ percentiles.

$24 \mathrm{~m}$, as compared to the dry season, despite the overall lower mixing ratios during this period. The less pronounced vertical gradient during the dry season could be due to a stronger turbulent mixing (Fig. 5).

Total monoterpene mixing ratios were extremely low during the wet season and rarely above the LOD $\left(\mathrm{LOD}_{\mathrm{MT}}=0.23 \mathrm{ppb}\right.$; Table 1$)$. For the dry season, the highest mixing ratios were found at the $24 \mathrm{~m}$ level, with a median of $1 \mathrm{ppb}$ (IQR 0.38) between 15:00 and 18:00 LT. The mixing ratios at $79 \mathrm{~m}$ as well as at the ground $(0.5 \mathrm{~m})$ were significantly lower than at $24 \mathrm{~m}$ between 15:00 and 18:00 LT (about more than a factor of 2). During the night, total monoterpene mixing ratios decreased but never reached zero values (Fig. 4).

\subsection{Oxidation products of isoprenoids}

Methyl vinyl ketone, methacrolein and ISOPOOH (hereafter referred to as isoprene oxidation products, $\mathrm{I}_{\mathrm{ox}}$ ) are key compounds for the analysis of the oxidation processes in the forest atmosphere as their predominant source is the oxidation of isoprene, the compound most copiously emitted by tropical forests. Dry and wet season data of isoprene oxidation products showed a clear seasonality and large differences in magnitudes between seasons (Fig. 6).

During the wet season, the highest median mixing ratios were found above the canopy with $0.22 \mathrm{ppb}$ (IQR 0.34) around 13:00 LT at $79 \mathrm{~m}$. This coincided with the peak of isoprene at $24 \mathrm{~m}$ during the same time of the day, suggesting that isoprene oxidation product production is at its maximum when isoprene emissions are the highest and that they are produced above the canopy shortly after the emission of isoprene. Mixing ratios for 24 and $0.5 \mathrm{~m}$ during the wet season remained almost constant during the night $(\leq 0.05 \mathrm{ppb})$ and only increased during daylight hours. Mixing ratios below the canopy were usually $0.1 \mathrm{ppb}$ lower than above the canopy throughout the day (Fig. 6). After sunset, the $79 \mathrm{~m}$ level mixing ratios of isoprene oxidation products did not decrease immediately as those at the $24 \mathrm{~m}$ level did. This may indicate a lower depletion in the dark at the top levels and a deposition to leaves and stems.

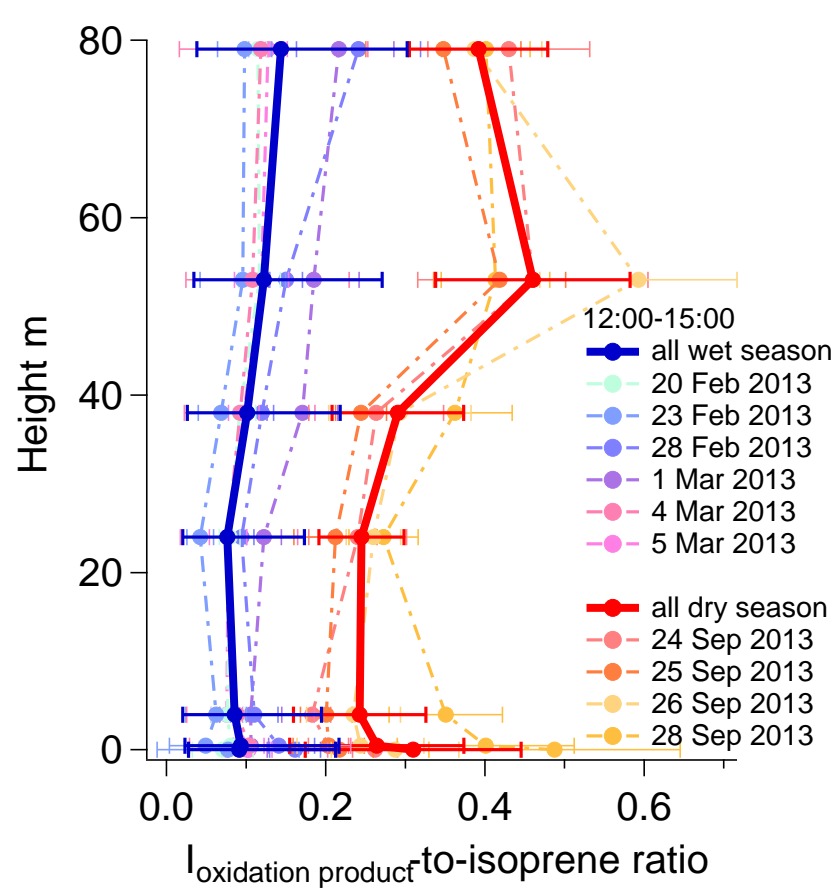

Figure 7. Average profiles of the isoprene oxidation product ( $\mathrm{I}_{\text {oxidation products }}$ )-to-isoprene ratio for the dry and wet season for the period of 12:00-15:00 LT for the whole measurement period (thick lines) and as single day analysis (dashed lines).

During the dry season, median mixing ratios of $\mathrm{I}_{\mathrm{Ox}}$ were higher above the canopy by 1 order of magnitude as compared to the wet season. For most times of the day, mixing ratios at $24 \mathrm{~m}$ matched those at $79 \mathrm{~m}$. The decrease of mixing ratios after sunset was similar at $24 \mathrm{~m}$ and $79 \mathrm{~m}$. This effect may be caused by a better turbulent mixing during the dry season, which allows for a faster oxidation of isoprene to isoprene oxidation products, as well as better atmospheric mixing of the isoprene oxidation products formed within the profile. The ground level mixing ratios showed a diurnal variability, which was not apparent in the wet season, though mixing ratios remained the lowest at this height.

An analysis of the ratio between isoprene and the isoprene oxidation products indicated changes in the oxidative 
patterns between the seasons. During the wet season, ratios never exceeded 0.2 , indicating there was not much oxidation taking place. $\mathrm{I}_{\mathrm{Ox}}$-to-isoprene ratios during the wet season were the lowest in the middle of the canopy $(24 \mathrm{~m})$, and increased near the ground and above the canopy. During the dry season, ratios increased at all heights indicating a higher oxidative capacity during this period. The ratios increased above the canopy, suggesting a clear formation of isoprene oxidation products at this height. Ratios were the highest at $53 \mathrm{~m}$; however, above the canopy (i.e from 38 to $79 \mathrm{~m}$ ) a high day-to-day variability (Fig. 7) was observed, dampening any dominance at $53 \mathrm{~m}$. It could be that above the canopy isoprene, which was emitted from the forest, was rapidly converted into isoprene oxidation products by $\mathrm{OH}$ and ozone.

\subsection{Acetaldehyde, acetone and methyl ethyl ketone}

Oxygenated VOCs such as acetaldehyde, acetone and MEK were grouped together. They exhibited similar variations over the day and season. In the wet season, acetaldehyde, acetone and MEK (Fig. 8) showed the highest mixing ratios at $24 \mathrm{~m}$ at midday, reaching medians of $0.94 \mathrm{ppb}$ (IQR 1.61), $0.98 \mathrm{ppb}$ (IQR 0.93) and $0.4 \mathrm{ppb}$ (IQR 0.58), respectively. With the highest mixing ratios found within the canopy, the diurnal cycle with a pronounced increase around 12:00 LT is consistent with biogenic emissions from canopy vegetation. Throughout the measurement period, the mixing ratios above the canopy and at the ground remained much lower than within the canopy $(24 \mathrm{~m})$, except for acetone. Of all three species, acetone was the only compound with higher mixing ratios above the canopy (up to $0.92 \mathrm{ppb}$ (IQR 0.53 ) at 12:00-15:00 LT), compared to within the canopy. For acetone, above-canopy mixing ratios were always higher than inside the canopy during daytime except for the period of 11:00-14:00 LT, where canopy mixing ratios $(24 \mathrm{~m})$ dominated (Fig. 8).

Conditions during the dry season were markedly different, with mixing ratios peaking above the canopy, instead of inside. Interestingly, the in-canopy mixing ratios of acetaldehyde were comparable to those of the wet season, whereas the $79 \mathrm{~m}$ level showed a 3-fold increase. Such differences clearly indicate a seasonal change in the dominating sources and sinks, as well as possible differences in the vertical mixing for this species. In a comparable fashion, acetone was also more abundant above canopy than within during the dry season. Similarly, MEK mixing ratios changed to comparable mixing ratios in and above the canopy during the dry season. Despite the 4-fold increase from the wet to the dry season at the $79 \mathrm{~m}$ level, mixing ratios within the canopy remained similar ( $\sim 400 \mathrm{ppt})$ as compared to the wet season, suggesting that the MEK within the canopy does not originate from isoprene oxidation (Bracho-Nunez et al., 2013). In addition, the vertical distribution of these oxygenated compounds during the dry season compared very well to the calculated isoprene oxidation product-to-isoprene ratio. Fur-
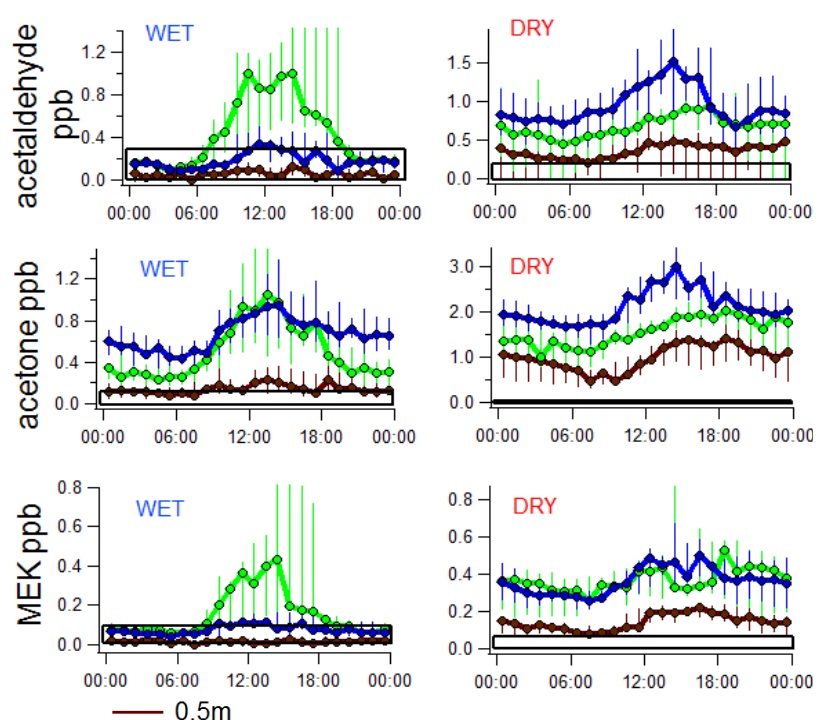

Heights $\begin{aligned}-24 \mathrm{~m} \\ -79 \mathrm{~m}\end{aligned}$

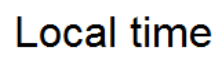

Figure 8. Diurnal medians for the wet season (left) and dry season (right), for acetaldehyde (top), acetone (middle) and methyl ethyl ketone (bottom) at different heights. Range bars are expressed as the 25 and $75 \%$ percentiles.

thermore, for the dry season, it seemed that whereas isoprene peaked at 13:00 LT, the oxygenated compounds (acetaldehyde, acetone and MEK) peaked from 15:00 to 18:00 LT. This suggested different processes involved in the formation of these compounds besides plant emission.

\subsection{Methanol and acetonitrile}

Up to $80 \%$ of the methanol data during the wet season were below the LOD (LOD Methanol, wet $=1.70 \mathrm{ppb}$, Table 1$)$. In contrast, during the dry season, the median mixing ratios for methanol were higher at about $4.7 \mathrm{ppb}$ (IQR 1.35) at $79 \mathrm{~m}$ during the period of 15:00-18:00 LT (Fig. 9). Mixing ratios at 79 and $24 \mathrm{~m}$ exhibited similar diurnal patterns with comparable magnitudes. Nevertheless, at 15:00 the within canopy mixing ratios slightly exceeded those above the canopy. This happened every day at the same time together with the peak in temperature (Fig. 9). Acetonitrile mixing ratios during the wet season period were the highest at $79 \mathrm{~m}$ with maximum mixing ratios of $0.1 \mathrm{ppb}$ (IQR 0.06) during daytime (medians of the period from 12:00 to 15:00). During the dry season, median mixing ratios for acetonitrile increased to up to $0.25 \mathrm{ppb}$ (IQR 0.06) at daytime (12:00-15:00 LT period), again with the highest mixing ratios above the canopy and at the canopy crown (Fig. 10). 


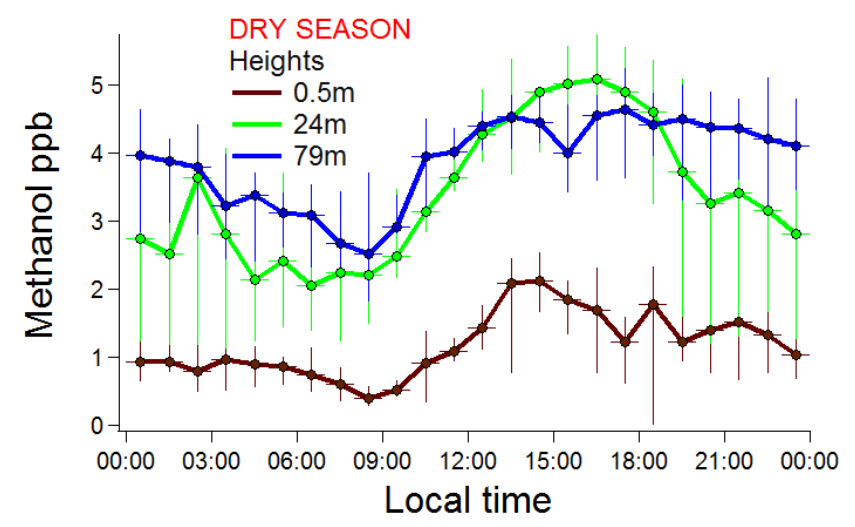

Figure 9. Diurnal hourly medians for methanol during the dry season at different heights. Range bars are expressed as the 25 and $75 \%$ percentiles.

\section{Discussion}

\subsection{Diel and seasonal behaviour}

The main climatic difference between the dry and the wet season in the central Amazonian terra firme rainforest is insolation, as the annual temperature variation is on average only $2{ }^{\circ} \mathrm{C}$ (Nobre et al., 2009). During the wet season, the insolation is quite reduced due to the extended cloud cover and rain events. Other forests such as boreal forest with a strong temperature annual variation from summer to winter exhibit changes of BVOC emissions during the growing season, and are greatly reduced during wintertime (Hakola et al., 1998, 2001, 2003; Raisanen et al., 2009). In mid-latitude deciduous forests, most trees lose all the leaves during wintertime and leaf photosynthesis ceases (Staudt et al., 2000; Holzke et al., 2006). Such seasonal variations are mainly due to changes in phenology and temperature (Schnitzler et al., 2002; Abbot, 2003).

The forest in central Amazonia does not seem to suffer from water limitation in any season (Restrepo-Coupe et al., 2013). High light and temperature during the dry season corresponds to photosynthesis rates and affects the related BVOC production pathways. Such climatic differences in the Amazon rainforest area during wet and dry season trigger seasonal growth rates which are mirrored in tree rings (Brienen and Zuidema, 2005; Zuidema et al., 2012; Restrepo-Coupe et al., 2013), indicating not only stronger growth during the wet season in terra firme rainforest (Dünisch et al., 2003) but also species-specific synchronous leaf flushing at the onset of the dry season.

A distinct seasonality in the magnitude of mixing ratios or the diel cycle was observed for all monitored compounds. During the wet season the fluctuations and mixing ratio levels of BVOCs seemed to be dominantly driven by biological processes, resulting in higher mixing ratios for isoprene, acetaldehyde, acetone and MEK inside the canopy. The general behaviour strongly suggested the main source to be at the forest canopy top height. This was not the case for isoprene oxidation products and acetonitrile, which exhibited the highest mixing ratios above the canopy. This observation was expected, as the isoprene oxidation products are produced by the oxidation of isoprene, released by vegetation and transported to above the canopy (Kesselmeier et al., 2002b). Similarly, acetonitrile was expected to be higher above the canopy as it was likely from regional biomass burning plumes that have been transported to the site (Kuhlbusch et al., 1991; Andreae and Merlet, 2001). Surprisingly, acetonitrile showed concentrations at the canopy top to be comparable to abovecanopy concentrations, both during wet and dry season, indicating a potential biogenic source (Nyalala et al., 2011, 2013). The mixing ratios of water soluble compounds, such as methanol, might also be influenced by the deposition to wet plant surfaces (Laffineur et al., 2012) emphasizing the seasonal trend that originated from reduced emissions during the wet season.

During the dry season, a different situation was observed. Higher mixing ratios of acetaldehyde, acetone, MEK, methanol, isoprene oxidation products and acetonitrile were detected above the canopy during both the day and nighttime. Most likely, this increase above the canopy was due to higher production of secondary VOCs such as acetaldehyde, acetone, isoprene oxidation products or methanol via oxidation of BVOCs primarily emitted from the forest. In addition, an increase in the variability of BVOC mixing ratios above the canopy was observed in the dry season, with mixing ratios inside the canopy sometimes reaching the above-canopy levels. Most likely, this was due to the higher insolation during the dry season, which resulted in high upper canopy leaf temperatures and turbulent mixing above the canopy during the day. Thus, this higher variability might also have been influenced by changing environmental conditions, seasonal differences in plant emission potential, variation in the oxidative capacity of the atmosphere, influencing secondary BVOC production rates, and transport of air masses from other regions. This could be seen in the weak gradients above the canopy, except for those of isoprene, which was additionally chemically depleted.

Furthermore, during the dry season, long-range transport of $\mathrm{NO}_{\mathrm{x}}$ enriched air masses from other regions, including biomass burning air masses, could have triggered a higher oxidative capacity of the air, as indicated by higher ozone and $\mathrm{NO}_{\mathrm{x}}$ concentrations at the ATTO site during the dry season (S. Wolff, personal communication, 2014). The rise of ozone and $\mathrm{NO}_{\mathrm{x}}$ during the dry season could intensifized atmospheric chemical reactions, due to the higher production of atmospheric oxidants such as $\mathrm{OH}$ and ozone itself (Rummel et al., 2007). These atmospheric conditions could have led to higher production of secondary BVOCs above the canopy as observed. Summarizing, the different mixing ratios and vertical patterns among seasons can be related to changes in insolation, temperature, external sources (i.e. 

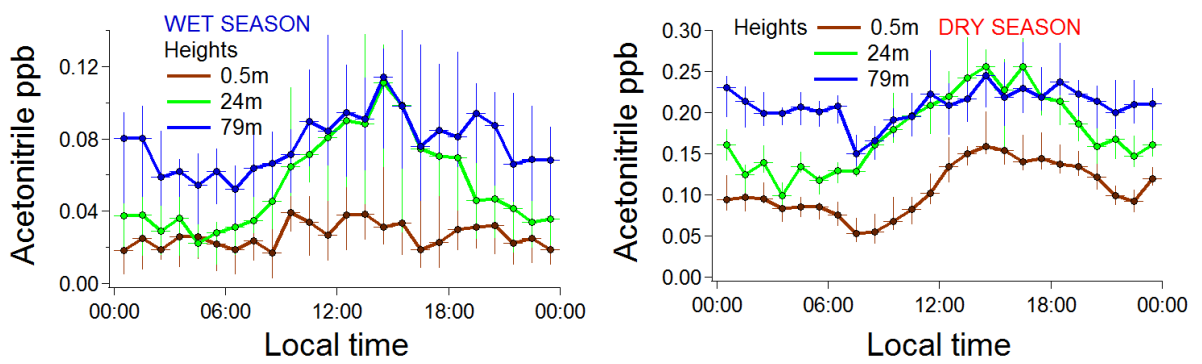

Figure 10. Diurnal hourly median acetonitrile mixing ratios during the wet season (left) and the dry season (right) for different heights. Range bars represent the 75 and the $25 \%$ percentiles.

biomass burning air masses during the dry season) and leaf phenology, all related to seasonality.

Isoprene and monoterpenes peaked together with light intensity just after midday inside the canopy during the dry and the wet season, but monoterpenes exhibited a slight broadening to later hours. Oxygenated compounds showed the highest mixing ratios at 15:00-16:00 LT during the dry season. This suggested that isoprene emissions are more closely related to radiation, which peaks at 12:00 LT. The oxygenated compounds, including isoprene oxidation products, produced directly by the forest plant species or by chemical reactions in the atmosphere may have been more related to temperature (which peaks at the same time: 15:00-16:00 LT) than to light. During both seasons, isoprene had the highest mixing ratios during the day at the top of the canopy where leaves received most of the radiation. After ceasing of photosynthesis and isoprene production during the night (Fig. 5), mixing ratios of isoprene decreased considerably towards the ground. Such a decrease just after sunset was too rapid to be explained exclusively by gas-phase chemistry due to the expected decrease of the $\mathrm{OH}$ levels which does not have major sources in the dark (Goldan et al., 1995). Furthermore, the ozonolysis of alkanes during the night can be neglected due to the low ozone levels (Paulson and Orlando, 1996; Andreae et al., 2002). Moreover, the development of the nocturnal boundary layer results in low transport rates (with a wind speed at $19 \mathrm{~m}$ of $0.23 \pm 0.17 \mathrm{~m} \mathrm{~s}^{-1}$ ) with diffusion being the main trigger. Under these conditions, development of the isoprene (the profile with lower mixing ratios to the ground during the night) clearly indicated a sink at the surfaces (such as leaves, soil and/or litter). Presumably isoprene was lost to biological consumption (Goldan et al., 1995; Cleveland and Yavitt, 1997; Gray et al., 2014).

Total monoterpenes presented a very strong seasonality with mixing ratios during the wet season below $0.23 \mathrm{ppb}$ and during the dry season up to $1.8 \mathrm{ppb}$ (maximum value). A few Amazonian tree species have been monitored for monoterpene emissions in previous studies, suggesting that more factors than solely meteorological can influence the seasonality of monoterpene emissions (Kuhn et al., 2004a, b; BrachoNunez et al., 2013; Jardine et al., 2015). Among those fac- tors are the oxidative capacity of the atmosphere and phenological development, which may be accentuated during the dry season especially during the transition between seasons (Kuhn et al., 2004a, b). In addition, during the dry season, total monoterpene mixing ratios exhibited a broader peak with some relation to the temperature. However, as the PTRMS measures the sum of monoterpenes, it is possible that the monoterpene composition changes seasonally along with their reactivities and vertical patterns (Kesselmeier et al., 2002b; Kuhn et al., 2004a, b; Jardine et al., 2015).

The ratio of isoprene oxidation products to isoprene provides an indication of the oxidative capacity of the atmosphere. Patterns of isoprene oxidation products clearly indicated changes in the oxidation processes at the Amazonian rainforest over the year. During the wet season, a low isoprene oxidation product-to-isoprene ratio, suggested a weak oxidative regime above the canopy, in contrast to the dry season, where higher ratios indicated a higher oxidative capacity. Even though mixing ratios of isoprene oxidation products and isoprene rose during the dry season, they did not rise proportionally compared to isoprene. Whereas isoprene had a 4-fold increase from the wet to the dry season, isoprene oxidation products had a 10 -fold increase, possibly indicating a faster depletion of isoprene than isoprene oxidation product production, as well as efficient deposition to wet surfaces during the wet season. This faster processing could also be observed in the more accentuated isoprene profiles despite the much higher variability observed during the dry season (Fig. 5). The $\mathrm{I}_{\mathrm{ox}}$-to-isoprene ratios during the dry season increased to about $75 \%$ compared to the wet season, and are comparable with ratios previously reported (Kesselmeier et al., 2002b) for Amazonian rainforest ecosystems (Fig. 7).

Regarding the vertical distributions of the other oxygenated VOCs above the canopy, a similarity of patterns became apparent. When $\mathrm{I}_{\mathrm{ox}}$-to-isoprene ratio above the canopy is used as a proxy for atmospheric oxidation, OVOC vertical profiles in the dry season could suggest that the oxidation of emitted VOCs above the canopy efficiently produced secondary BVOCs such as acetaldehyde and acetone. Despite the high variability, a maximum of oxidative capacity was generally observed at $53 \mathrm{~m}$. 
Table 2. Mixing ratios of isoprene, methanol, acetaldehyde, acetone, acetonitrile, MEK, isoprene oxidation products $\left(\mathrm{I}_{\mathrm{Ox}}\right)$ and total monoterpenes measured at different Amazonian forest sites. In the second column different sites can be found: Duke reserve is a scientific research site $25 \mathrm{~km}$ north-east of Manaus ( $\left.2^{\circ} 55^{\prime} \mathrm{S}, 59^{\circ} 59^{\prime} \mathrm{W}\right)$; Peru $\left(4^{\circ} 35^{\prime} 15^{\prime \prime} \mathrm{S} 77^{\circ} 28^{\prime} 00^{\prime \prime} \mathrm{W}\right)$; Balbina $100 \mathrm{~km}$ north-east of Manaus $\left(1^{\circ} 59^{\prime} \mathrm{S}\right.$, $\left.59.12^{\prime} \mathrm{W}\right)$; $\mathrm{C} 14$ a tower in the Reserva Biologica de Cuieiras, $50 \mathrm{~km}$ NW of Manaus $\left(2^{\circ} 28^{\prime} \mathrm{S}, 60^{\circ} 09^{\prime} \mathrm{W}\right)$; Surinam $\left(2-5^{\circ} \mathrm{N}, 54-57^{\circ} \mathrm{W}\right)$; Jaru, Rondônia: is the Rebio do Jaru natural reserve in Rondônia $\left(10^{\circ} 04^{\prime} 55^{\prime \prime} \mathrm{S}, 61^{\circ} 55^{\prime} 48^{\prime \prime} \mathrm{W}\right)$; K34 is a tower located in the Reserva Biologica de Cueiras $\left(2^{\circ} 35^{\prime} 33^{\prime \prime} \mathrm{S}, 60^{\circ} 12^{\prime} 27^{\prime \prime} \mathrm{W}\right)$; TT34 is located in the same reserve $\left(2^{\circ} 35.37^{\prime} \mathrm{S}, 60^{\circ} 06.92^{\prime} \mathrm{W}\right)$; ATTO-INSTANT tower is located in coordinates $2^{\circ} 08^{\prime} 39^{\prime \prime} \mathrm{S}, 58^{\circ} 59^{\prime} 59^{\prime \prime} \mathrm{W}$. Seasons are specified together with the exact timing of sampling (Dry: dry season, Wet: wet season, D-t-W: dry-to-wet season transition and W-t-D: wet-to-dry season transition). Heights are reported as metres except for those non-specified, such as surface and mixed layer (ML). Values are reported as medians and means during daylight periods as reported in the references. The values from this study are median values of the period from 12:00 to 15:00 LT during both seasons, except for total monoterpenes, methanol, acetaldehyde and $\mathrm{I}_{\mathrm{Ox}}$, which in the dry season had higher median mixing ratios from 15:00 to 18:00 LT. All values are in ppb. The subscript numbers represent: 1: value reported as mean, 2: mean of reported range values, 3: value reported as maxima, 4: value reported as median.

\begin{tabular}{|c|c|c|c|c|c|c|c|c|c|c|c|}
\hline Season & Site & Height & Isoprene & Methanol & Acetaldehyde & Acetone & Acetonitrile & $\mathrm{I}_{\mathrm{OX}}$ & MEK & $\begin{array}{l}\text { Total } \\
\text { monoterpenes }\end{array}$ & Reference \\
\hline Dry - Jul 2001 & K34 & 52 & 3.40 & - & - & - & - & - & - & 0.34 & Kuhn et al. $(2007)_{1}$ \\
\hline Dry - Jul 2001 & K34 & ML & 4.70 & - & - & - & - & 0.50 & - & 0.23 & Kuhn et al. $(2007)_{2}$ \\
\hline $\begin{array}{l}\text { Dry - } \\
\text { Aug/Sep } 2004\end{array}$ & $\mathrm{C} 14$ & 40 & 7.80 & 4.10 & 1.20 & 2.20 & - & 2.10 & - & 0.87 & Karl et al. $(2007)_{2}$ \\
\hline $\begin{array}{l}\text { Dry - } \\
\text { Aug/Sep } 2004\end{array}$ & $\mathrm{C} 14$ & ML & 5.50 & 3.50 & 1.50 & 2.20 & - & 2.30 & - & 0.52 & Karl et al. $(2007)_{2}$ \\
\hline Dry - Jul 2000 & Santarem & 47 & 4.50 & - & - & - & - & - & - & 0.90 & Rinne et al. $(2002)_{3}$ \\
\hline Dry - Jun 1984 & $\begin{array}{l}\text { Manaus- } \\
\text { Humaitá }\end{array}$ & surface & 2.40 & - & - & - & - & - & - & 2.86 & $\begin{array}{l}\text { Greenberg and } \\
\text { Zimmerman }(1984)_{1}\end{array}$ \\
\hline Dry - Sep 2013 & ATTO & 0.05 & 3.13 & 1.51 & 0.56 & 1.23 & 0.14 & 0.65 & 0.20 & 0.53 & This study $_{4}$ \\
\hline Dry - Sep 2013 & ATTO & 0.5 & 3.77 & 1.63 & 0.45 & 1.22 & 0.15 & 0.61 & 0.19 & 0.55 & This study $_{4}$ \\
\hline Dry - Sep 2013 & ATTO & 4 & 5.35 & 1.79 & 0.47 & 1.38 & 0.19 & 0.72 & 0.22 & 0.70 & This study $_{4}$ \\
\hline Dry - Sep 2013 & ATTO & 24 & 7.62 & 5.04 & 0.82 & 1.68 & 0.25 & 2.34 & 0.43 & 1.02 & This study $_{4}$ \\
\hline Dry - Sep 2013 & ATTO & 38 & 6.13 & 4.70 & 1.26 & 2.75 & 0.24 & 1.94 & 0.49 & 0.86 & This study $_{4}$ \\
\hline Dry - Sep 2013 & ATTO & 53 & 5.72 & 5.44 & 2.04 & 3.48 & 0.25 & 2.80 & 0.53 & 0.89 & This study $_{4}$ \\
\hline Dry - Sep 2013 & ATTO & 79 & 4.81 & 4.57 & 1.35 & 2.74 & 0.22 & 2.27 & 0.48 & 0.69 & This study $_{4}$ \\
\hline $\begin{array}{l}\text { Dry and D-t-W } \\
\text { transition } \\
\text { Sep-Dec } 2010\end{array}$ & TT34 & 2 & 2.20 & - & - & - & - & - & - & 0.55 & Jardine et al. (2011b) 1 \\
\hline $\begin{array}{l}\text { Dry and D-t-W } \\
\text { transition } \\
\text { Sep-Dec } 2010\end{array}$ & TT34 & 2 & - & - & - & - & - & 0.80 & - & - & Jardine et al. (2011a) $)_{1}$ \\
\hline $\begin{array}{l}\text { Dry and D-t-W } \\
\text { transition } \\
\text { Sep-Dec } 2010\end{array}$ & TT34 & 11 & 3.20 & - & - & - & - & - & - & 0.76 & Jardine et al. $(2011 b)_{1}$ \\
\hline $\begin{array}{l}\text { Dry and D-t-W } \\
\text { transition } \\
\text { Sep-Dec } 2010\end{array}$ & TT34 & 11 & - & - & - & - & - & 1.15 & - & - & Jardine et al. (2011a) 1 \\
\hline $\begin{array}{l}\text { Dry and D-t-W } \\
\text { transition } \\
\text { Sep-Dec } 2010\end{array}$ & TT34 & 17 & 3.20 & - & - & - & - & - & - & 0.82 & Jardine et al. $(2011 b)_{1}$ \\
\hline $\begin{array}{l}\text { Dry and D-t-W } \\
\text { transition } \\
\text { Sep-Dec } 2010\end{array}$ & TT34 & 17 & - & - & - & - & - & 1.20 & - & - & Jardine et al. (2011a) 1 \\
\hline $\begin{array}{l}\text { Dry and D-t-W } \\
\text { transition } \\
\text { Sep-Dec } 2010\end{array}$ & TT34 & 24 & 2.90 & - & - & - & - & - & - & 0.80 & Jardine et al. (2011b) 1 \\
\hline $\begin{array}{l}\text { Dry and D-t-W } \\
\text { transition } \\
\text { Sep-Dec } 2010\end{array}$ & TT34 & 24 & - & - & - & - & - & 1.30 & - & - & Jardine et al. (2011a) 1 \\
\hline $\begin{array}{l}\text { Dry and D-t-W } \\
\text { transition } \\
\text { Sep-Dec } 2010\end{array}$ & TT34 & 30 & 2.80 & - & - & - & - & - & - & 0.75 & Jardine et al. $(2011 b)_{1}$ \\
\hline $\begin{array}{l}\text { Dry and D-t-W } \\
\text { transition } \\
\text { Sep-Dec } 2010\end{array}$ & TT34 & 30 & - & - & - & - & - & 1.32 & - & - & Jardine et al. (2011a) 1 \\
\hline $\begin{array}{l}\text { Dry and D-t-W } \\
\text { transition } \\
\text { Sep-Dec } 2010\end{array}$ & TT34 & 40 & 2.75 & - & - & - & - & - & - & 0.70 & Jardine et al. $(2011 b)_{1}$ \\
\hline $\begin{array}{l}\text { Dry and D-t-W } \\
\text { transition } \\
\text { Sep-Dec } 2010\end{array}$ & TT34 & 40 & - & - & - & - & - & 1.30 & - & - & Jardine et al. (2011a) \\
\hline
\end{tabular}


Table 2.

\begin{tabular}{|c|c|c|c|c|c|c|c|c|c|c|c|}
\hline Season & Site & Height & Isoprene & Methanol & Acetaldehyde & Acetone & Acetonitrile & $\mathrm{I}_{\mathrm{OX}}$ & MEK & $\begin{array}{l}\text { Total } \\
\text { monoterpenes }\end{array}$ & Reference \\
\hline $\begin{array}{l}\text { Dry and D-t-W } \\
\text { transition } \\
\text { Sep-Oct } 1999\end{array}$ & $\begin{array}{l}\text { Jaru, } \\
\text { Rondônia }\end{array}$ & 52 & 15.00 & 3.00 & $\sim 3.5$ & 0.30 & - & $\sim 0.7$ & - & $\sim 0.5$ & Kesselmeier et al. (2002) \\
\hline Dry - Jul-Aug 1985 & Manaus & 30 & 2.65 & - & - & - & - & - & - & 0.27 & Zimmerman et al. (1988) 4 \\
\hline Dry - Jun 1984 & Guyana & ML & 2.00 & - & - & - & - & - & - & - & Gergory et al. (1986) \\
\hline Dry - Jun 1996 & Peru & 2 & 3.31 & - & - & - & - & 1.24 & - & 0.22 & Helmig et al. (1998) \\
\hline Dry - Jun 1996 & Peru & ML & 1.69 & - & - & - & - & 0.87 & - & 0.22 & Helmig et al. (1998) \\
\hline Dry - Sep 2004 & C14 & 53 & 7.80 & 3.50 & $<1.5$ & 1.75 & 0.20 & - & - & 0.29 & Rizzo et al. $(2010)_{3}$ \\
\hline Dry - Jul-Aug 1985 & $\begin{array}{l}\text { Duke } \\
\text { reserve }\end{array}$ & 1 & $\sim 3.00$ & - & - & - & - & - & - & - & Rasmussen and Khalil, $1988_{1}$ \\
\hline $\begin{array}{l}\text { D-t-W and Wet - } \\
\text { Nov 2013-Jul } 2014\end{array}$ & K34 & 29 & - & - & - & - & - & - & - & 1.3 & Jardine et al. (2015) 1 \\
\hline Wet - Feb 1999 & Rondônia & ML & 6.68 & - & - & - & - & - & - & 0.69 & Greenberg et al. (2004) 1 \\
\hline Wet - Feb-Mar 2013 & ATTO & 0.05 & 0.57 & $<1.70$ & $<0.28$ & 0.22 & $<0.04$ & 0.04 & $<0.09$ & $<0.23$ & This study $_{4}$ \\
\hline Wet - Feb-Mar 2013 & ATTO & 0.5 & 0.57 & $<1.70$ & $<0.28$ & 0.22 & 0.04 & 0.04 & $<0.09$ & $<0.23$ & This study $_{4}$ \\
\hline Wet - Feb-Mar 2013 & ATTO & 4 & 0.86 & $<1.70$ & $<0.28$ & 0.23 & 0.06 & 0.06 & $<0.09$ & $<0.23$ & This study $_{4}$ \\
\hline Wet - Feb-Mar 2013 & ATTO & 24 & 2.29 & $<1.70$ & 0.94 & 0.98 & 0.09 & 0.15 & 0.38 & $<0.23$ & This study $_{4}$ \\
\hline Wet - Feb-Mar 2013 & ATTO & 38 & 2.39 & $<1.70$ & 0.47 & 1.16 & 0.10 & 0.20 & 0.13 & $<0.23$ & This study $_{4}$ \\
\hline Wet - Feb-Mar 2013 & ATTO & 53 & 1.85 & $<1.70$ & 0.33 & 0.94 & 0.08 & 0.20 & 0.12 & $<0.23$ & This study $_{4}$ \\
\hline Wet - Feb-Mar 2013 & ATTO & 79 & 1.69 & $<1.70$ & 0.31 & 0.92 & 0.10 & 0.22 & 0.11 & $<0.23$ & This study $_{4}$ \\
\hline Wet - Jan-Feb 2000 & Tapajós & ML & 0.54 & - & - & - & - & - & - & 0.08 & Greenberg et al. (2004) 1 \\
\hline Wet - Mar 1988 & Surinam & ML & 3.30 & 4.00 & - & - & - & $\sim 1.5$ & - & - & Warneke et al. $(2001)_{2}$ \\
\hline Wet - Mar 1998 & Surinam & ML & 1.70 & 1.10 & 1.70 & 2.90 & 0.19 & 1.30 & 1.80 & $<0.3$ & Williams et al. (2001) \\
\hline Wet - Mar 1998 & Surinam & ML & - & - & - & 2.60 & - & - & - & - & Pöschl et al. (2001) \\
\hline Wet - Mar 1998 & $\begin{array}{l}\text { Balbina } \\
\text { main }\end{array}$ & ML & 2.30 & - & - & - & - & - & - & 0.20 & Greenberg et al. (2004) 1 \\
\hline Wet - Mar 1998 & $\begin{array}{l}\text { Balbina } \\
50 \mathrm{~km} \mathrm{~W}\end{array}$ & ML & 2.90 & - & - & - & - & - & - & 0.21 & Greenberg et al. (2004) 1 \\
\hline Wet - Mar 1998 & $\begin{array}{l}\text { Balbina } \\
5 \mathrm{~km} \mathrm{~W}\end{array}$ & ML & 2.10 & - & - & - & - & - & - & 0.25 & Greenberg et al. (2004) 1 \\
\hline Wet-Mar-Apr 1998 & $\mathrm{C} 14$ & 1.5 & 7.10 & - & - & - & - & 0.47 & - & 0.36 & Kesselmeier et al. $(2000)_{1}$ \\
\hline Wet-Mar-Apr 1998 & Balbina & 1.5 & 6.00 & - & - & - & - & 0.43 & - & 0.68 & Kesselmeier et al. $(2000)_{1}$ \\
\hline Wet-Mar-Apr 1998 & $\mathrm{C} 14$ & 30 & 7.50 & - & - & - & - & 0.30 & - & 0.51 & Kesselmeier et al. $(2000)_{1}$ \\
\hline Wet-Mar-Apr 1998 & $\mathrm{C} 14$ & 50 & 6.13 & - & - & - & - & 0.62 & - & 0.46 & Kesselmeier et al. $(2000)_{1}$ \\
\hline Wet - Mar-Apr 1998 & Balbina & ML & 3.00 & - & - & - & - & 1.90 & - & 0.14 & Kesselmeier et al. $(2000)_{1}$ \\
\hline $\begin{array}{l}\text { W-t-D transition } \\
\text { - Apr-May } 1999\end{array}$ & Rondônia & 52 & 4.00 & - & $\sim 0.5$ & 1.00 & - & $\sim 0.5$ & - & $\sim 0.4$ & Kesselmeier et al. $(2002)_{2}$ \\
\hline $\begin{array}{l}\text { W-t-D transition - } \\
\text { Apr-May } 1999\end{array}$ & Rondônia & 52 & - & - & 1.85 & - & - & - & - & - & Rottenberger et al. $(2004)_{3}$ \\
\hline $\begin{array}{l}\text { W-t-D transition - } \\
\text { May } 1999\end{array}$ & Rondônia & 25 & 8.00 & - & - & - & - & - & - & 0.15 & Kuhn et al. (2002) 3 \\
\hline
\end{tabular}

The vertical profiles of acetone, MEK and acetaldehyde during the wet season showed a maximum inside the canopy at midday. Acetaldehyde is reported to be emitted by the forest crown as a by-product of fermentation processes within roots due to water flooding and root anoxia (Kesselmeier et al., 2009; Bracho-Nunez et al., 2013). If rain events cause such an anoxia, this would explain the observed mixing ratios below the LOD ( $\mathrm{LOD}_{\text {acetaldehyde }} 0.28 \mathrm{ppb}$ ) in the understorey, a considerable increase at the crown, and a quick decrease towards the atmosphere during the wet season. A similar pattern, indicating plant production, was found for acetone and MEK, which is supported by other studies (Isidorov et al., 1985; Kirstine et al., 1998; Fall, 2003; Bracho-Nunez et al., 2013). However, for the vertical profile of acetone during the dry season, the peak was observed above the canopy, possibly due to a dominance of photochemistry just above the canopy (Seco et al., 2007). MEK, however, showed a less pronounced increase above the canopy. In fact, it seems that during the wet season MEK was only emitted by plants and not originating from isoprene oxidation (Bracho-Nunez et al., 2013). During the dry season, the higher mixing ra- tios above the canopy indicated possible production from isoprene oxidation, although plant emission could not be disregarded (Isidorov et al., 1985; Kirstine et al., 1998; de Gouw et al., 1999; Davison et al., 2008; Jardine et al., 2010). For all these compounds we should also consider a possible bidirectional exchange, where the canopy crown could be acting as a sink (Kesselmeier, 2001; Rottenberger et al., 2004; Karl et al., 2005; Park et al., 2013; Niinemets et al., 2014).

Methanol behaved similarly to other oxygenated compounds. During the wet season, mixing ratios were below detection limit. This could have been caused by lower plant production and deposition to wet surfaces (Laffineur et al., 2011). For the dry season, the overall higher mixing ratios above the canopy were consistent with both enhanced photochemical production within the troposphere and transport of biomass burning impacted air masses. However, higher mixing ratios within the canopy in the afternoon (15:00) indicated the potential of a biogenic methanol emission due to pectin lamella aging in cell walls during leaf growth (Galbally and Kirstine, 2002; Kesselmeier et al., 2009). Leaf area index measurements demonstrated a growth of the canopy 
during the period of July 2013 to September 2013 (G. Martins, personal communication, 2014).

Acetonitrile is currently regarded to be primarily emitted from biomass burning sources with an oceanic and photochemical sink, but a biogenic source cannot be excluded (Bange and Williams, 2000; Andreae and Merlet, 2001; Nyalala et al., 2011, 2013). Our data differed significantly between the seasons with mixing ratios 2.5 times higher during the dry season than detected in the wet season, which is consistent with an influence from biomass burning in September 2013. Distinct biomass burning plumes were not observed. This indicates that there was no biomass burning close by affecting our measurements, and impact from longrange transport may be assumed. Such burning activities can be expected during this time of the year (Karl et al., 2007). In addition, the observation that levels decrease towards the ground could indicate a potential uptake by soil bacteria, although wet deposition cannot be excluded. The variability of the measurements especially inside the canopy hides a possible influence by plant emissions which has previously been reported (Bange and Williams, 2000; Nyalala et al., 2011, 2013).

\subsection{Comparison to other observations in Amazonian rainforest ecosystems}

The Amazonian ecosystem is characterized by great variability of plant species, though regional considerations prove a hyperdominance by a smaller species number (Ter Steege et al., 2013). Thus, atmospheric BVOC levels and compositions exhibit similar variations. The overview of the investigated BVOCs, as given in Table 2, was assembled from literature values (for isoprene, monoterpenes, acetaldehyde, acetone, MEK, isoprene oxidation products, methanol and acetonitrile). As compared to other more reactive compounds, isoprene has been the most measured compound, due to its high abundance and the availability of techniques. Although isoprene values reported in this study generally agree with previous reports, some of our median values for isoprene in the wet season are the lowest reported. Furthermore, we measured at 0.05 and $0.5 \mathrm{~m}$, which were not reported for an Amazonian ecosystem before, though it is needed to characterize the isoprene behaviour close to the ground. Monoterpene mixing ratios for this study were high, although they were far from the highest total monoterpene mixing ratio reported by Greenberg and Zimmerman (1984). The values compare to ecosystems such as boreal forests, known to strongly emit monoterpenes. For instance, a mean mixing ratio of $1.1 \mathrm{ppb}$ was observed in Hyytiälä, Finland, during July, when the highest emissions occur (Raisanen et al., 2009), as compared to mean mixing ratios for monoterpenes of $1 \mathrm{ppb}$ during the dry season in this study. In agreement with Kanakidou et al. (2005), further efforts on monoterpene characterization in terms of abundance and reactivity in Amazonia are needed for a better understanding of SOA growth and formation pro- cesses, regionally as well as worldwide. In addition, the oxidative capacity of the atmosphere can be studied based on the oxidation products of isoprene. Across the Amazon region mixing ratios of isoprene oxidation products are always higher above the canopy and during the dry season (Table 2), especially when measured in the mixed layer by aircrafts (Karl et al., 2007; Kuhn et al., 2007) or tethered balloons (Kesselmeier et al., 2000) and suggest a higher oxidative capacity during the dry season above the canopy.

The reported values in the literature for acetaldehyde, methanol, acetone and MEK are too scarce to make reliable conclusions. Among the studies listed in Table 2, we reported the highest mixing ratios for acetone and methanol; acetonitrile seems to match previous measurements. The lack of surface measurements of MEK does not allow for a comparison. More continuous measurements with a better representation in space and height are needed to investigate the seasonality of within- and above-canopy interactions with the atmosphere to improve our understanding of BVOC emissions, transport and chemistry over Amazonia (Greenberg and Zimmerman, 1984; Gregory et al., 1986; Rasmussen and Khalil, 1988; Zimmerman et al., 1988; Helmig et al., 1998; Kesselmeier et al., 2000, 2002b; Warneke et al., 2001; Williams et al., 2001; Rinne et al., 2002; Greenberg et al., 2004; Rottenberger et al., 2004; Pöschl, 2001; Karl et al., 2007; Kuhn et al., 2007; Rizzo et al., 2010; Jardine et al., 2011a, b,; Jardine et al., 2015).

\section{Conclusions}

Our first BVOC measurements at the ATTO site provide unique information about the role of these compounds in the central Amazon rainforest area within and above the canopy. Marked seasonality and diel variance was observed at the site, as seen in the BVOC mixing ratios seasonality and vertical profiles. These changes in BVOC mixing ratios were attributed to changing sources of these compounds mainly in relation to seasonal fluctuations of light, temperature and phenology. During the wet season, BVOCs seemed to be dominantly produced by vegetation, and mixing ratios are the highest within the canopy. During the dry season additional atmospheric BVOC sources became apparent. Mixing ratios increased in magnitude and presented a different diurnal pattern with respect to the wet season. This picture indicated a mixture of sources such as vegetation emissions, oxidation from primary emitted BVOCs and regional atmospheric transport as well as sinks such as deposition, photochemistry and transport.

The summary of BVOC mixing ratios in the Amazonian ecoregion (Table 2) shows an enormous variation depending on site, height and season. Year-round continuous measurements are required in order to improve our understanding of the within canopy BVOC dynamics and their interac- 
tion with the atmospheric chemistry in such biodiverse ecoregions forming the Amazonian rainforest.

Acknowledgements. We thank the Max Planck Society and the Instituto Nacional de Pesquisas da Amazonia for continuous support. Furthermore, we acknowledge the support by the ATTO project (German Federal Ministry of Education and Research, BMBF funds 01LB1001A; Brazilian Ministério da Ciência, Tecnologia e Inovação FINEP/MCTI contract 01.11.01248.00); UEA and FAPEAM, LBA/INPA and SDS/CEUC/RDS-Uatumã. We would like to especially thank all the people involved in the logistical support of the ATTO project, in particular Reiner Ditz and Hermes Braga Xavier. We acknowledge the Micrometeorological group of the INPA/LBA for their collaboration concerning the meteorological parameters, with special thanks to Marta Sá, Antonio Huxley and Leonardo Oliveira. We are grateful to Tracey W. Andreae for help with the manuscript, Guenther Schebeske for the GC-FID analysis and Nina Knothe for logistical help. We would also like to thank Thomas Klüpfel for all the great support provided with the PTR-MS operation in the laboratory as well as in the field. Lastly, we would like to acknowledge the referees of this manuscript for the extensive contributions and suggestions which helped to improve this study.

The article processing charges for this open-access publication have been covered by the Max Planck Society.

Edited by: R. Holzinger

\section{References}

Abbot, D. S.: Seasonal and interannual variability of North American isoprene emissions as determined by formaldehyde column measurements from space, Geophys. Res. Lett., 30, 1886, doi:10.1029/2003GL017336, 2003.

Andreae, M. O.: The Biosphere: Pilot or passenger on spaceship Earth?, in Contributions to Global Change Research, edited by D. Heinen, S. Hoch, T. Krafft, C. Moss, S. P., and A. Welschhoff, 59-66, German National Committee on Global Change Research, Bonn, 2001.

Andreae, M. O.: Aerosols Before Pollution, Science, 315, 50-51, doi:10.1126/science.1136529, 2007.

Andreae, M. O. and Merlet, P.: Emission of trace gases and aerosols from biomass burning, Global Biogeochem. Cy., 15, 955-966, doi:10.1029/2000gb001382, 2001.

Andreae, M. O., Artaxo, P., Brandao, C., Carswell, F. E., Ciccioli, P., da Costa, A. L., Culf, A. D., Esteves, J. L., Gash, J. H. C., Grace, J., Kabat, P., Lelieveld, J., Malhi, Y., Manzi, A. O., Meixner, F. X., Nobre, A. D., Nobre, C., Ruivo, M., Silva-Dias, M. A., Stefani, P., Valentini, R., von Jouanne, J., and Waterloo, M. J.: Biogeochemical cycling of carbon, water, energy, trace gases, and aerosols in Amazonia: The LBA-EUSTACH experiments, J. Geophys. Res., 107, 8066, doi:10.1029/2001jd000524, 2002.

Araujo, A. C., Nobre, A. D., Kruijt, B., Elbers, J. A., Dallarosa, R., Stefani, P., von Randow, C., Manzi, A. O., Culf, A. D., Gash, J. H. C., Valentini, R., and Kabat, P.: Comparative measurements of carbon dioxide fluxes from two nearby towers in a central Amazonian rainforest: The Manaus LBA site, J. Geophys. Res., 107, 8090, doi:10.1029/2001jd000676, 2002.

Artaxo, P., Rizzo, L., Paixão, M., de Lucca, S., Oliveira, P. H. F., Lara, L. L., Weidemann, K. T., Andreae, M. O., Holben, B., Schafer, J., Correia, A. L., and Pauliquevis, T. M.: Aerosol particles in Amazonia: their composition, role in the radiation balance, cloud formation, and nutrient cycles, in Amazonia and global change, vol. 186, edited by: Keller, M., Bustamante, M., Gash, J. H. C., and Silva Dias, P., 233-250, American Geophysical Union, Washington DC, 2009.

Artaxo, P., Rizzo, L. V., Brito, J. F., Barbosa, H. M. J., Arana, A., Sena, E. T., Cirino, G. G., Bastos, W., Martin, S. T., and Andreae, M. O.: Atmospheric aerosols in Amazonia and land use change: from natural biogenic to biomass burning conditions, Faraday Discuss., 165, 203, doi:10.1039/c3fd00052d, 2013.

Atkinson, R. and Arey, J.: Atmospheric Degradation of Volatile Organic Compounds Atmospheric Degradation of Volatile Organic Compounds, Chem. Rev., 103, 4605-4638, doi:10.1021/cr0206420, 2003.

Bange, H. W. and Williams, J.: New Directions: Acetonitrile in atmospheric and biogeochemical cycles, Atmos. Environ., 34, 4959-4960, doi:10.1016/S1352-2310(00)00364-2, 2000.

Boucher, O., Randall, D., Artaxo, P., Bretherton, C., Feingold, G., Forster, P., Kerminen, V.-M., Kondo, Y., Liao, H., Lohmann, U., Rasch, P., Satheesh, S. K., Sherwood, S., Stevens, B. and Zhang, X. Y.: Clouds and Aerosols., in Climate Change 2013: The Physical Science Basis. Contribution of Working Group I to the Fifth Assessment Report of the Intergovernmental Panel on Climate Change (IPCC), edited by: Stocker, T. F., Qin, D., Plattner, G.-K., Tignor, M., Allen, S. K., Boschung, J., Nauels, A., Xia, Y., Bex, V., and Midgley, P. M., 571-657, Cambridge University Press, Cambridge UK and New York USA, 2013.

Bourtsoukidis, E., Bonn, B., and Noe, S. M.: On-line field measurements of BVOC emissions from Norway spruce (Picea abies) at the hemiboreal SMEAR-Estonia site under autumn conditions, Boreal Environ. Res., 19, 153-167, 2014.

Bracho-Nunez, A., Knothe, N., Costa, W. R., Maria Astrid, L. R., Kleiss, B., Rottenberger, S., Piedade, M. T., and Kesselmeier, J.: Root anoxia effects on physiology and emissions of volatile organic compounds (VOC) under short- and long-term inundation of trees from Amazonian floodplains, Springerplus, 1, 9, doi:10.1186/2193-1801-1-9, 2012.

Bracho-Nunez, A., Knothe,, N. M., Welter, S., Staudt, M., Costa, W. R., Liberato, M. A. R., Piedade, M. T. F., and Kesselmeier, J.: Leaf level emissions of volatile organic compounds (VOC) from some Amazonian and Mediterranean plants, Biogeosciences, 10, 5855-5873, doi:10.5194/bg-10-5855-2013, 2013.

Brienen, R. J. W. and Zuidema, P. A.: Relating tree growth to rainfall in Bolivian rain forests: a test for six species using tree ring analysis, Oecologia, 146, 1-12, doi:10.1007/s00442-005-0160$\mathrm{y}, 2005$.

Carlton, A. G., Wiedinmyer, C., and Kroll, J. H.: A review of Secondary Organic Aerosol (SOA) formation from isoprene, Atmos. Chem. Phys. Discuss., 9, 8261-8305, doi:10.5194/acpd-9-82612009, 2009.

Chan, M. N., Surratt, J. D., Claeys, M., Edgerton, E. S., Tanner, R. L., Shaw, S. L., Zheng, M., Knipping, E. M., Eddingsaas, N. C., Wennberg, P. O., and Seinfeld, J. H.: Characterization and 
quantification of isoprene-derived epoxydiols in ambient aerosol in the southeastern United States., Environ. Sci. Technol., 44, 4590-6, doi:10.1021/es100596b, 2010.

Cleveland, C. C. and Yavitt, J. B.: Consumption of atmospheric isoprene in soil, Geophys. Res. Lett., 24, 2379, doi:10.1029/97GL02451, 1997.

Claeys, M., Graham, B., Vas, G., Wang, W., Vermeylen, R., Pashynska, V., Cafmeyer, J., Guyon, P., Andreae, M. O., Artaxo, P., and Maenhaut, W.: Formation of secondary organic aerosols through photooxidation of isoprene, Science, 303, 1173-1176, doi:10.1126/science.1092805, 2004.

Crutzen, P. J. and Andreae, M. O.: Biomass burning in the tropics - Impact on atmospheric chemistry and biogeochemical cycles, Science, 250, 1669-1678, 1990.

Crutzen, P. J., Williams, J., Poschl, U., Hoor, P., Fischer, H., Warneke, C., Holzinger, R., Hansel, A., Lindinger, W., Scheeren, B. and Lelieveld, J.: High spatial and temporal resolution measurements of primary organics and their oxidation products over the tropical forests of Surinam, Atmos. Environ., 34, 1161-1165, doi:10.1016/s1352-2310(99)00482-3, 2000.

Davidson, E. A., de Araujo, A. C., Artaxo, P., Balch, J. K., Brown, I. F., C. Bustamante, M. M., Coe, M. T., DeFries, R. S., Keller, M., Longo, M., Munger, J. W., Schroeder, W., Soares-Filho, B. S., Souza, C. M. and Wofsy, S. C.: The Amazon basin in transition, Nature, 481, 321-32, 2012.

Davison, B., Brunner, A., Ammann, C., Spirig, C., Jocher, M., and Neftel, A.: Cut-induced VOC emissions from agricultural grasslands., Plant Biol., 10, 76-85, doi:10.1055/s-2007-965043, 2008.

De Gouw, J. and Warneke, C.: Measurements of volatile organic compounds in the earth's atmosphere using proton-transferreaction mass spectrometry, Mass Spectrom. Rev., 26, 223-257, doi:10.1002/mas.20119, 2007.

De Gouw, J. A., Howard, C. J., Custer, T. G., and Fall, R.: Emissions of volatile organic compounds from cut grass and clover are enhanced during the drying process, Geophys. Res. Lett., 26, 811-814, doi:10.1029/1999GL900076, 1999.

De Gouw, J. A., Goldan, P. D., Warneke, C., Kuster, W. C., Roberts, J. M., Marchewka, M., Bertman, S. B., Pszenny, A. A. P., and Keene, W. C.: Validation of proton transfer reaction-mass spectrometry (PTR-MS) measurements of gasphase organic compounds in the atmosphere during the New England Air Quality Study (NEAQS) in 2002, 108, 1-18, doi:10.1029/2003JD003863, 2003.

Doerffel, R. A.: Statistik in der analytischen Chemie, 3, Verlag Chemie, Weinheim, Germany, 51-72, 1984.

Dünisch, O., Montóia, V. R. and Bauch, J.: Dendroecological investigations on Swietenia macrophylla King and Cedrela odorata L. (Meliaceae) in the central Amazon, Trees, 17, 244-250, doi:10.1007/s00468-002-0230-2, 2003.

Fall, R.: Abundant oxygenates in the atmosphere: a biochemical perspective., Chem. Rev., 103, 4941-52, doi:10.1021/cr0206521, 2003.

Fall, R. and Benson, A. A.: Leaf methanol - The simplest natural product from plants, Trends Plant Sci., 1, 296-30, 1996.

Folkers, A., Hüve, K., Ammann, C., Dindorf, T., Kesselmeier, J., Kleist, E., Kuhn, U., Uerlings, R., and Wildt, J.: Methanol emissions from deciduous tree species: dependence on temperature and light intensity, Plant Biol., 10, 65-75, doi:10.1111/j.14388677.2007.00012.x, 2008.
Galbally, I. E. and Kirstine, W.: The Production of Methanol by Flowering Plants and the Global Cycle of Methanol, J. Atmos. Chem., 43, 195-229, doi:10.1023/A:1020684815474, 2002.

Goldan, P. D., Kuster, W. C., Fehsenfeld, F. C., and Montzka, S. A.: Hydrocarbon measurements in the southeastern United States: The Rural Oxidants in the Southern Environment (ROSE) Program 1990, J. Geophys. Res., 100, 25945, doi:10.1029/95JD02607, 1995.

Grant, D. D., Fuentes, J. D., Chan, S., Stockwell, W. R., Wang, D., and Ndiaye, S. A.: Volatile organic compounds at a rural site in western Senegal, J. Atmos. Chem., 60, 19-35, doi:10.1007/s10874-008-9106-1, 2008.

Gray, C. M., Monson, R. K., and Fierer, N.: Biotic and abiotic controls on biogenic volatile organic compound fluxes from a subalpine forest floor, J. Geophys. Res. Biogeosci., 119, 547-556, doi:10.1002/2013JG002575, 2014.

Greenberg, J. P. and Zimmerman, P. R.: Nonmethane hydrocarbons in remote tropical, continental, and marine atmospheres, J. Geophys. Res., 89, 4767, doi:10.1029/JD089iD03p04767, 1984.

Greenberg, J. P., Guenther, A. B., Petron, G., Wiedinmyer, C., Vega, O., Gatti, L. V., Tota, J., and Fisch, G.: Biogenic VOC emissions from forested Amazonian landscapes, Glob. Change Biol., 10, 651-662, doi:10.1111/j.1365-2486.2004.00758.x, 2004.

Gregory, G. L., Harriss, R. C., Talbot, R. W., Rasmussen, R. A., Garstang, M., Andreae, M. O., Hinton, R. R., Browell, E. V., Beck, S. M., Sebacher, D. I., Khalil, M. A. K., Ferek, R. J., and Harriss, S. V.: Air chemistry over the tropical forest of Guyana, J. Geophys. Res., 91, 8603, doi:10.1029/JD091iD08p08603, 1986.

Hakola, H., Rinne, J., and Laurila, T.: The hydrocarbon emission rates of tea-leafed willow (Salix phylicifolia), silver birch (Betula pendula) and European aspen (Populus tremula), Atmos. Environ., 32, 1825-1833, doi:10.1016/S1352-2310(97)00482-2, 1998.

Hakola, H., Laurila, T., Lindfors, V., Hellén, H., Gaman, A., and Rinne, J.: Variation of the VOC emission rates of birch species during the growing season, Boreal Environ. Res., 6, 237-249, 2001.

Hakola, H., Tarvainen, V., Laurila, T., Hiltunen, V., Hellén, H., and Keronen, P.: Seasonal variation of VOC concentrations above a boreal coniferous forest, Atmos. Environ., 37, 1623-1634, doi:10.1016/S1352-2310(03)00014-1, 2003.

Hallquist, M., Wenger, J. C., Baltensperger, U., Rudich, Y., Simpson, D., Claeys, M., Dommen, J., Donahue, N. M., George, C., Goldstein, A. H., Hamilton, J. F., Herrmann, H., Hoffmann, T., Iinuma, Y., Jang, M., Jenkin, M. E., Jimenez, J. L., Kiendler-Scharr, A., Maenhaut, W., McFiggans, G., Mentel, Th. F., Monod, A., Prévôt, A. S. H., Seinfeld, J. H., Surratt, J. D., Szmigielski, R., and Wildt, J.: The formation, properties and impact of secondary organic aerosol: current and emerging issues, Atmos. Chem. Phys., 9, 5155-5236, doi:10.5194/acp-95155-2009, 2009.

Helmig, D., Balsley, B., Davis, K., Kuck, L. R., Jensen, M., Bognar, J., Smith, T., Arrieta, R. V, Rodriguez, R., and Birks, J. W.: Vertical profiling and determination of landscape fluxes of biogenic nonmethane hydrocarbons within the planetary boundary layer in the Peruvian Amazon, J. Geophys. Res., 103, 25519-25532, 1998.

Holzke, C., Hoffmann, T., Jaeger, L., Koppmann, R., and Zimmer, W.: Diurnal and seasonal variation of monoterpene and sesquiter- 
pene emissions from Scots pine (Pinus sylvestris L.), Atmos. Environ., 40, 3174-3185, doi:10.1016/j.atmosenv.2006.01.039, 2006.

Isidorov, V. A., Zenkevich, I. G., and Ioffe, B. V.: Volatile organic compounds in the atmosphere of forests, Atmos. Environ., 19, $1-8,1985$.

Jardine, A. B., Jardine, K. J., Fuentes, J. D., Martin, S. T., Martins, G., Durgante, F., Carneiro, V., Higuchi, N., Manzi, A. O., and Chambers, J. Q.: Highly reactive lightdependent monoterpenes in the Amazon, Geophys. Res. Lett., 42, doi:10.1002/2014GL062573, 2015

Jardine, K., Harley, P., Karl, T., Guenther, A., Lerdau, M., and Mak, J. E.: Plant physiological and environmental controls over the exchange of acetaldehyde between forest canopies and the atmosphere, Biogeosciences, 5, 1559-1572, doi:10.5194/bg-5-15592008, 2008.

Jardine, K., Abrell, L., Kurc, S. A., Huxman, T., Ortega, J., and Guenther, A.: Volatile organic compound emissions from Larrea tridentata (creosotebush), Atmos. Chem. Phys., 10, 1219112206, doi:10.5194/acp-10-12191-2010, 2010.

Jardine, K. J., Monson, R. K., Abrell, L., Saleska, S. R., Arneth, A., Jardine, A., Ishida, F. Y., Serrano, A. M. Y., Artaxo, P., Karl, T., Fares, S., Goldstein, A., Loreto, F., and Huxman, T.: Within-plant isoprene oxidation confirmed by direct emissions of oxidation products methyl vinyl ketone and methacrolein, Global Chang. Biol., 18, 973-984, doi:10.1111/j.1365-2486.2011.02610.x, 2011a.

Jardine, K. J., Yañez Serrano, A., Arneth, A., Abrell, L., Jardine, A., van Haren, J., Artaxo, P., Rizzo, L. V, Ishida, F. Y., Karl, T., Kesselmeier, J., Saleska, S., and Huxman, T.: Within-canopy sesquiterpene ozonolysis in Amazonia, J. Geophys. Res., 116, D19301, doi:10.1029/2011jd016243, 2011b.

Jardine, K. J., Meyers, K., Abrell, L., Alves, E. G., Yanez Serrano, A. M., Kesselmeier, J., Karl, T., Guenther, A., Vickers, C., and Chambers, J. Q.: Emissions of putative isoprene oxidation products from mango branches under abiotic stress, J. Exp. Bot., 64, 3697-3709, doi:10.1093/jxb/ert202, 2013.

Kanakidou, M., Seinfeld, J. H., Pandis, S. N., Barnes, I., Dentener, F. J., Facchini, M. C., Van Dingenen, R., Ervens, B., Nenes, A., Nielsen, C. J., Swietlicki, E., Putaud, J. P., Balkanski, Y., Fuzzi, S., Horth, J., Moortgat, G. K., Winterhalter, R., Myhre, C. E. L., Tsigaridis, K., Vignati, E., Stephanou, E. G. and Wilson, J.: Organic aerosol and global climate modelling: a review, Atmos. Chem. Phys., 5, 1053-1123, doi:10.5194/acp-5-1053-2005, 2005.

Karl, T. G., Spirig, C., Rinne, J., Stroud, C., Prevost, P., Greenberg, J., Fall, R., and Guenther, A.: Virtual disjunct eddy covariance measurements of organic compound fluxes from a subalpine forest using proton transfer reaction mass spectrometry, Atmos. Chem. Phys., 2, 279-291, doi:10.5194/acp-2-279-2002, 2002.

Karl, T., Potosnak, M., Guenther, A., Clark, D., Walker, J., Herrick, J. D. and Geron, C.: Exchange processes of volatile organic compounds above a tropical rain forest: Implications for modeling tropospheric chemistry above dense vegetation, J. Geophys. Res., 109, D18306, doi:10.1029/2004JD004738, 2004.

Karl, T., Harley, P., Guenther, A., Rasmussen, R., Baker, B., Jardine, K., and Nemitz, E.: The bi-directional exchange of oxygenated VOCs between a loblolly pine (Pinus taeda) plantation and the at- mosphere, Atmos. Chem. Phys., 5, 3015-3031, doi:10.5194/acp5-3015-2005, 2005.

Karl, T., Guenther, A., Yokelson, R. J., Greenberg, J., Potosnak, M., Blake, D. R., and Artaxo, P.: The tropical forest and fire emissions experiment: Emission, chemistry, and transport of biogenic volatile organic compounds in the lower atmosphere over Amazonia, J. Geophys. Res., 112, D18302, doi:10.1029/2007JD008539, 2007.

Karl, T., Guenther, A., Turnipseed, A., Tyndall, G., Artaxo, P., and Martin, S.: Rapid formation of isoprene photo-oxidation products observed in Amazonia, Atmos. Chem. Phys., 9, 7753-7767, doi:10.5194/acp-9-7753-2009, 2009.

Kaser, L., Karl, T., Schnitzhofer, R., Graus, M., Herdlinger-Blatt, I. S., DiGangi, J. P., Sive, B., Turnipseed, A., Hornbrook, R. S., Zheng, W., Flocke, F. M., Guenther, A., Keutsch, F. N., Apel, E., and Hansel, A.: Comparison of different real time VOC measurement techniques in a ponderosa pine forest, Atmos. Chem. Phys., 12, 27955-27988, doi:10.5194/acpd-12-27955-2012, 2013.

Kesselmeier, J.: Exchange of short-chain oxygenated volatile organic compounds (VOCs) between plants and the atmosphere: A compilation of field and laboratory studies, J. Atmos. Chem., 39(3), 219-233, 2001.

Kesselmeier, J. and Staudt, M.: Biogenic volatile organic compounds (VOC): An overview on emission, physiology and ecology, J. Atmos. Chem., 33(1), 23-88, 1999.

Kesselmeier, J., Bode, K., Hofmann, U., Müller, H., Schäfer, L., Wolf, A., Ciccioli, P., Brancaleoni, E., Cecinato, A., Frattoni, M., Foster, P., Ferrari, C., Jacob, V., Fugit, J. L., Dutaur, L., Simon, V., and Torres, L.: Emission of short chained organic acids, aldehydes and monoterpenes from Quercus ilex L. and Pinus pinea L. in relation to physiological activities, carbon budget and emission algorithms, Atmos. Environ., 31 (Supplement 1), 119-133, doi:10.1016/S1352-2310(97)00079-4, 1997.

Kesselmeier, J., Kuhn, U., Wolf, A., Andreae, M. O., Ciccioli, P., Brancaleoni, E., Frattoni, M., Guenther, A., Greenberg, J., Vasconcellos, P. D., de Oliva, T., Tavares, T. and Artaxo, P.: Atmospheric volatile organic compounds (VOC) at a remote tropical forest site in central Amazonia, Atmos. Environ., 34, 4063-4072, 2000.

Kesselmeier, J., Ciccioli, P., Kuhn, U., Stefani, P., Biesenthal, T., Rottenberger, S., Wolf, A., Vitullo, M., Valentini, R., Nobre, A., Kabat, P., and Andreae, M. O.: Volatile organic compound emissions in relation to plant carbon fixation and the terrestrial carbon budget, Global Biogeochem. Cycles, 16, 73-1-73-9, doi:10.1029/2001GB001813, 2002a.

Kesselmeier, J., Kuhn, U., Rottenberger, S., Biesenthal, T., Wolf, A., Schebeske, G., Andreae, M. O., Ciccioli, P., Brancaleoni, E., Frattoni, M., Oliva, S. T., Botelho, M. L., Silva, C. M. A., and Tavares, T. M.: Concentrations and species composition of atmospheric volatile organic compounds (VOCs) as observed during the wet and dry season in Rondonia (Amazonia), J. Geophys. Res., 107, 1-13, doi:10.1029/2000jd000267, 2002b.

Kesselmeier, J., Guenther, A., Hoffmann, T., Piedade, M. T., and Warnke, J.: Natural volatile organic compound emissions from plants and their roles in oxidant balance and particle formation, in: Amazonia and global change, 186, edited by: Keller, M., Bustamante, M., Gash, J. H. C., and Silva Dias, P., 183-206, Am. Geophys. Union, Washington DC., 2009. 
Kirstine, W., Galbally, I., Ye, Y., and Hooper, M.: Emissions of volatile organic compounds (primarily oxygenated species) from pasture, J. Geophys. Res., 103, 10605, doi:10.1029/97JD03753, 1998.

Koppmann, R. and Wildt, J.: Oxygenated Volatile Organic Compound, in Volatile Organic Compounds in the Atmosphere, edited by: Koppmann, R., Blackwell Publishing Ltd, Oxford, UK, 129173, 2007.

Kuhlbusch, T. A., Lobert, J. M., Crutzen, P. J., and Warneck, P.: Molecular nitrogen emissions from denitrification during biomass burning, Nature, 351, 135-137, doi:10.1038/351135a0, 1991.

Kuhn, U., Rottenberger, S., Biesenthal, T., Wolf, A., Schebeske, G., Ciccioli, P., Brancaleoni, E., Frattoni, M., Tavares, T. M., and Kesselmeier, J.: Isoprene and monoterpene emissions of Amazonian tree species during the wet season: Direct and indirect investigations on controlling environmental functions, J. Geophys. Res., 107, 8071, doi:10.1029/2001jd000978, 2002.

Kuhn, U., Rottenberger, S., Biesenthal, T., Wolf, A., Schebeske, G., Ciccioli, P., Brancaleoni, E., Frattoni, M., Tavares, T. M., and Kesselmeier, J.: Seasonal differences in isoprene and light-dependent monoterpene emission by Amazonian tree species, Global Chang. Biol., 10, 663-682, doi:10.1111/j.15298817.2003.00771.x, 2004a.

Kuhn, U., Rottenberger, S., Biesenthal, T., Wolf, A., Schebeske, G., Ciccioli, P., and Kesselmeier, J. Strong correlation between isoprene emission and gross photosynthetic capacity during leaf phenology of the tropical tree species Hymenaea courbaril with fundamental changes in VOC emission composition during early leaf development. Plant Cell Environ., 27, 1469-1485, doi:10.1111/j.1365-3040.2004.01252.x, 2004b.

Kuhn, U., Andreae, M. O., Ammann, C., Araújo, A. C., Brancaleoni, E., Ciccioli, P., Dindorf, T., Frattoni, M., Gatti, L. V., Ganzeveld, L., Kruijt, B., Lelieveld, J., Lloyd, J., Meixner, F. X., Nobre, A. D., Pösschl, U., Spirig, C., Stefani, P., Thielmann, A., Valentini, R., and Kesselmeier, J.: Isoprene and monoterpene fluxes from Central Amazonian rainforest inferred from towerbased and airborne measurements, and implications on the atmospheric chemistry and the local carbon budget, Atmos. Chem. Phys., 7, 2855-2879, doi:10.5194/acp-7-2855-2007, 2007.

Kuhn, U., Ganzeveld, L., Thielmann, A., Dindorf, T., Schebeske, G., Welling, M., Sciare, J., Roberts, G., Meixner, F. X., Kesselmeier, J., Lelieveld, J., Kolle, O., Ciccioli, P., Lloyd, J., Trentmann, J., Artaxo, P. and Andreae, M. O.: Impact of Manaus City on the Amazon Green Ocean atmosphere: ozone production, precursor sensitivity and aerosol load, Atmos. Chem. Phys., 10(19), 9251-9282, doi:10.5194/acp-10-9251-2010, 2010.

Laffineur, Q., Aubinet, M., Schoon, N., Amelynck, C., Müller, J. F., Dewulf, J., Van Langenhove, H., Steppe, K., and Heinesch, B.: Abiotic and biotic control of methanol exchanges in a temperate mixed forest, Atmos. Chem. Phys., 12, 577-590, doi:10.5194/acp-12-577-2012, 2012.

Laothawornkitkul, J., Taylor, J. E., Paul, N. D., and Hewitt, C. N.: Biogenic volatile organic compounds in the Earth system., New Phytol., 183, 27-51, doi:10.1111/j.1469-8137.2009.02859.x, 2009.

Lelieveld, J., Butler, T. M., Crowley, J. N., Dillon, T. J., Fischer, H., Ganzeveld, L., Harder, H., Lawrence, M. G., Martinez, M.,
Taraborrelli, D., and Williams, J.: Atmospheric oxidation capacity sustained by a tropical forest, Nature, 452, 737-740, 2008.

Lindinger, W., Hansel, A. and Jordan, A.: On-line monitoring of volatile organic compounds atpptv levels by means of proton-transfer-reaction mass spectrometry (PTR-MS) medical applications, food control and environmental research, Int. J. Mass Spectrom. Ion Process., 173, 191-241, doi:10.1016/S01681176(97)00281-4, 1998.

Liu, Y. J., Herdlinger-Blatt, I., McKinney, K. A., and Martin, S. T.: Production of methyl vinyl ketone and methacrolein via the hydroperoxyl pathway of isoprene oxidation, Atmos. Chem. Phys., 13, 5715-5730, doi:10.5194/acp-13-5715-2013, 2013.

Lobert, J. M., Scharffe, D. H., Hao, W. M., and Crutzen, P. J.: Importance of biomass burning in the atmospheric budgets of nitrogencontaining gases, Nature, 346, 552-554, doi:10.1038/346552a0, 1990.

Malhi, Y., Wood, D., Baker, T. R., Wright, J., Phillips, O. L., Cochrane, T., Meir, P., Chave, J., Almeirda, S., Arroyo, L., Higuiri, N., Killeen, T. J., Laurance, S. G., Laurance, W., Lewis, S. L., Monteagudo, A., Neill, D. A., Vargas, P. N., Pitman, N. C. A., Quesada, C. A., Salomao, R., Silva, J. N. M., Lezama, A. T., Terborgh, J., Martinez, R. V. and Vinceti, B.: The regional variation of aboveground live biomass in oldgrowth Amazonian forests, Global Chang. Biol., 12, 1107-1138, doi:10.1111/j.1365-2486.2006.01120.x, 2006.

McKeen, S. A., Gierczak, T., Burkholder, J. B., Wennberg, P. O., Hanisco, T. F., Keim, E. R., Gao, R.-S., Liu, S. C., Ravishankara, A. R., and Fahey, D. W.: The photochemistry of acetone in the upper troposphere: A source of odd-hydrogen radicals, Geophys. Res. Lett., 24, 3177-3180, doi:10.1029/97GL03349, 1997.

Misztal, P. K., Nemitz, E., Langford, B., Di Marco, C. F., Phillips, G. J., Hewitt, C. N., MacKenzie, a. R., Owen, S. M., Fowler, D., Heal, M. R., and Cape, J. N.: Direct ecosystem fluxes of volatile organic compounds from oil palms in South-East Asia, Atmos. Chem. Phys., 11, 8995-9017, doi:10.5194/acp-11-89952011, 2011.

Niinemets, Ü., Fares, S., Harley, P., and Jardine, K. J.: Bidirectional exchange of biogenic volatiles with vegetation: emission sources, reactions, breakdown and deposition, Plant. Cell Environ., 37, 1790-809, doi:10.1111/pce.12322, 2014.

Nobre, C. A., Obregón, G. O., Marengo, J. A., Fu, R., and Poveda, G.: Characteristics of Amazonian climate: Main features, Geophys. Monogr. Ser., 186, 149-162, doi:10.1029/2008GM000720, 2009.

Nyalala, S. O., Petersen, M. A., and Grout, B. W. W.: Acetonitrile (methyl cyanide) emitted by the African spider plant (Gynandropsis gynandra L. (Briq)): Bioactivity against spider mite (Tetranychus urticae Koch) on roses, Sci. Hortic., 128, 352-356, doi:10.1016/j.scienta.2011.01.036, 2011.

Nyalala, S. O., Petersen, M. A. and Grout, B. W. W.: Volatile compounds from leaves of the African spider plant (Gynandropsis gynandra) with bioactivity against spider mite (Tetranychus urticae), Ann. Appl. Biol., 162, 290-298, doi:10.1111/aab.12021, 2013.

Park, J.-H., Goldstein, A. H., Timkovsky, J., Fares, S., Weber, R., Karlik, J., and Holzinger, R.: Active atmosphere-ecosystem exchange of the vast majority of detected volatile organic compounds. Science, 341, 643-647, doi:10.1126/science.1235053, 2013. 
Pauliquevis, T., Lara, L. L., Antunes, M. L., and Artaxo, P.: Aerosol and precipitation chemistry measurements in a remote site in Central Amazonia: the role of biogenic contribution, Atmos. Chem. Phys., 12, 4987-5015, doi:10.5194/acp-12-4987-2012, 2012.

Paulot, F., Crounse, J. D., Kjaergaard, H. G., Kürten, A., St Clair, J. M., Seinfeld, J. H. and Wennberg, P. O.: Unexpected epoxide formation in the gas-phase photooxidation of isoprene., Science, 325, 730-733, doi:10.1126/science.1172910, 2009.

Paulson, S. E. and Orlando, J. J.: The reactions of ozone with alkenes: An important source of $\mathrm{HO} \mathrm{x}$ in the boundary layer, Geophys. Res. Lett., 23, 3727-3730, doi:10.1029/96GL03477, 1996.

Pöschl, U., Williams, J., Hoor, P., Fischer, H., Crutzen, P. J., Warneke, C., Holzinger, R., Hansel, A., Jordan, A., Lindinger, W., Scheeren, H. A., Peters, W., and Lelieveld, J.: High acetone concentrations throughout the $0-12 \mathrm{~km}$ altitude range over the tropical rainforest in Surinam, J. Atmos. Chem., 38, 115-132, doi:10.1023/A:1006370600615, 2001.

Pye, H. O. T., Pinder, R. W., Piletic, I. R., Xie, Y., Capps, S. L., Lin, Y.-H., Surratt, J. D., Zhang, Z., Gold, A., Luecken, D. J., Hutzell, W. T., Jaoui, M., Offenberg, J. H., Kleindienst, T. E., Lewandowski, M., and Edney, E. O.: Epoxide pathways improve model predictions of isoprene markers and reveal key role of acidity in aerosol formation., Environ. Sci. Technol., 47, 1105611064, doi:10.1021/es402106h, 2013.

Raisanen, T., Ryyppo, A., and Kellomaki, S.: Monoterpene emission of a boreal Scots pine (Pinus sylvestris L.) forest, Agric. For. Meteorol., 149, 808-819, doi:10.1016/j.agrformet.2008.11.001, 2009.

Rasmussen, R. A. and Khalil, M. A. K.: Isoprene over the Amazon Basin, J. Geophys. Res., 93, 1417, doi:10.1029/JD093iD02p01417, 1988.

Restrepo-Coupe, N., da Rocha, H. R., Hutyra, L. R., da Araujo, A. C., Borma, L. S., Christoffersen, B., Cabral, O. M. R., de Camargo, P. B., Cardoso, F. L., da Costa, A. C. L., Fitzjarrald, D. R., Goulden, M. L., Kruijt, B., Maia, J. M. F., Malhi, Y. S., Manzi, A. O., Miller, S. D., Nobre, A. D., von Randow, C., Sá, L. D. A., Sakai, R. K., Tota, J., Wofsy, S. C., Zanchi, F. B., and Saleska, S. R.: What drives the seasonality of photosynthesis across the Amazon basin? A cross-site analysis of eddy flux tower measurements from the Brasil flux network, Agric. For. Meteorol., 182-183, 128-144, doi:10.1016/j.agrformet.2013.04.031, 2013.

Rinne, H. J. I., Guenther, A. B., Greenberg, J. P., and Harley, P. C.: Isoprene and monoterpene fluxes measured above Amazonian rainforest and their dependence on light and temperature, Atmos. Environ., 36, 2421-2426, 2002.

Rinne, J., Ruuskanen, T. M., Reissell, A., Taipale, R., Hakola, H., and Kulmala, M.: On-line PTR-MS measurements of atmospheric concentrations of volatile organic compounds in a European boreal forest ecosystem, Boreal Environ. Res., 10, 425-436, 2005.

Rivera-Rios, J. C., Nguyen, T. B., Crounse, J. D., Jud, W., St. Clair, J. M., Mikoviny, T., Gilman, J. B., Lerner, B. M., Kaiser, J. B., de Gouw, J., Wisthaler, A., Hansel, A., Wennberg, P. O., Seinfeld, J. H., and Keutsch, F. N.: Conversion of hydroperoxides to carbonyls in field and laboratory instrumentation: observational bias in diagnosing pristine versus anthropogenically- controlled atmospheric chemistry., Geophys. Res. Lett., 41, doi:10.1002/2014GL061919, 2014.

Rizzo, L. V, Artaxo, P., Karl, T., Guenther, A. B., and Greenberg, J.: Aerosol properties, in-canopy gradients, turbulent fluxes and VOC concentrations at a pristine forest site in Amazonia, Atmos. Environ., 44, 503-511, doi:10.1016/j.atmosenv.2009.11.002, 2010.

Rottenberger, S., Kuhn, U., Wolf, A., Schebeske, G., Oliva, S. T., Tavares, T. M. and Kesselmeier, J.: Exchange of short-chain aldehydes between Amazonian vegetation and the atmosphere, Ecol. Appl., 14, S247-S262, doi:10.1890/01-6027, 2004.

Rummel, U., Ammann, C., Kirkman, G. A., Moura, M. A. L., Foken, T., Andreae, M. O., and Meixner, F. X.: Seasonal variation of ozone deposition to a tropical rain forest in southwest Amazonia, Atmos. Chem. Phys., 7, 5415-5435, doi:10.5194/acp-75415-2007, 2007.

Sakulyanontvittaya, T., Milford, J., Guenther, A., Helmig, D., and Wiedinmyer, C.: Secondary organic aerosol from sesquiterpene and monoterpene emissions in the United States, Environ. Sci. Technol., 42, 8784-8790, 2008.

Schnitzler, J.-P., Bauknecht, N., Brüggemann, N., Einig, W., Forkel, R., Hampp, R., Heiden, A. C., Heizmann, U., Hoffmann, T., Holzke, C., Jaeger, L., Klauer, M., Komenda, M., Koppmann, R., Kreuzwieser, J., Mayer, H., Rennenberg, H., Smiatek, G., Steinbrecher, R., Wildt, J., and Zimmer, W.: Emission of Biogenic Volatile Organic Compounds: An Overview of Field, Laboratory and Modelling Studies Performed during the 'Tropospheric Research Program' (TFS) 1997-2000, J. Atmos. Chem., 42, 159177, doi:10.1023/A:1015757129946, 2002.

Seco, R., Penuelas, J., and Filella, I.: Short-chain oxygenated VOCs: Emission and uptake by plants and atmospheric sources, sinks, and concentrations, Atmos. Environ., 41, 2477-2499, doi:10.1016/j.atmosenv.2006.11.029, 2007.

Staudt, M., Bertin, N., Frenzel, B., and Seufert, G.: Seasonal Variation in Amount and Composition of Monoterpenes Emitted by Young Pinus pinea Trees - Implications for Emission Modeling, J. Atmos. Chem., 35, 77-99, doi:10.1023/A:1006233010748, 2000.

Surratt, J. D., Chan, A. W. H., Eddingsaas, N. C., Chan, M., Loza, C. L., Kwan, A. J., Hersey, S. P., Flagan, R. C., Wennberg, P. O., and Seinfeld, J. H.: Reactive intermediates revealed in secondary organic aerosol formation from isoprene., Proc. Natl. Acad. Sci. U. S. A., 107, 6640-6645, doi:10.1073/pnas.0911114107, 2010.

Tani, A., Hayward, S., and Hewitt, C. N.: Measurement of monoterpenes and related compounds by proton transfer reaction-mass spectrometry (PTR-MS), Int. J. Mass Spectrom., 223-224, 561578, doi:10.1016/S1387-3806(02)00880-1, 2003.

Ter Steege, H., Pitman, N. C. A., Sabatier, D., Baraloto, C., Salomão, R. P., Guevara, J. E., Phillips, O. L., Castilho, C. V, Magnusson, W. E., Molino, J.-F., Monteagudo, A., Núñez Vargas, P., Montero, J. C., Feldpausch, T. R., Coronado, E. N. H., Killeen, T. J., Mostacedo, B., Vasquez, R., Assis, R. L., Terborgh, J., Wittmann, F., Andrade, A., Laurance, W. F., Laurance, S. G. W., Marimon, B. S., Marimon, B.-H., Guimarães Vieira, I. C., Amaral, I. L., Brienen, R., Castellanos, H., Cárdenas López, D., Duivenvoorden, J. F., Mogollón, H. F., Matos, F. D. de A., Dávila, N., García-Villacorta, R., Stevenson Diaz, P. R., Costa, F., Emilio, T., Levis, C., Schietti, J., Souza, P., Alonso, A., Dallmeier, F., Montoya, A. J. D., Fernandez Piedade, M. 
T., Araujo-Murakami, A., Arroyo, L., Gribel, R., Fine, P. V. A., Peres, C. A., Toledo, M., Aymard C, G. A., Baker, T. R., Cerón, C., Engel, J., Henkel, T. W., Maas, P., Petronelli, P., Stropp, J., Zartman, C. E., Daly, D., Neill, D., Silveira, M., Paredes, M. R., Chave, J., Lima Filho, D. de A., Jørgensen, P. M., Fuentes, A., Schöngart, J., Cornejo Valverde, F., Di Fiore, A., Jimenez, E. M., Peñuela Mora, M. C., Phillips, J. F., Rivas, G., van Andel, T. R., von Hildebrand, P., Hoffman, B., Zent, E. L., Malhi, Y., Prieto, A., Rudas, A., Ruschell, A. R., Silva, N., Vos, V., Zent, S., Oliveira, A. A., Schutz, A. C., Gonzales, T., Trindade Nascimento, M., Ramirez-Angulo, H., Sierra, R., Tirado, M., Umaña Medina, M. N., van der Heijden, G., Vela, C. I. A., Vilanova Torre, E., Vriesendorp, C., Wang, O., Young, K. R., Baider, C., Ferreira, C., Mesones, I., Torres-Lezama, A., Urrego Giraldo, L. E., Zagt, R., Alexiades, M. N., Hernandez, L., HuamantupaChuquimaco, I., Milliken, W., Palacios Cuenca, W., Pauletto, D., Valderrama Sandoval, E., Valenzuela Gamarra, L., Dexter, K. G., Feeley, K., Lopez-Gonzalez, G., and Silman, M. R.: Hyperdominance in the Amazonian tree flora., Science, 342, 1243092, doi:10.1126/science.1243092, 2013.

Warneke, C., Holzinger, R., Hansel, A., Jordan, A., Lindinger, W., Pöschl, U., Williams, J., Hoor, P., Fischer, H., Crutzen, P. J., Scheeren, H. A., and Lelieveld, J.: Isoprene and its oxidation products methyl vinyl ketone, methacrolein, and isoprene related peroxides measured online over the tropical rain forest of Surinam in March 1998, J. Atmos. Chem., 38, 167-185, doi:10.1023/A:1006326802432, 2001.
Warneke, C., De Gouw, J. A., Kuster, W. C., Goldan, P. D., Fall, R., and Oceanic, N.: Validation of atmospheric VOC measurements by proton-transfer-reaction mass spectrometry using a gaschromatographic preseparation method. Environ. Sci. Technol., 37, 2494-2501, doi:10.1021/es026266i, 2003.

Williams, J.: Organic Trace Gases in the Atmosphere?: An Overview, 125-136, doi:10.1071/EN04057, 2004.

Williams, J., Poschl, U., Crutzen, P. J., Hansel, A., Holzinger, R., Warneke, C., Lindinger, W., and Lelieveld, J.: An atmospheric chemistry interpretation of mass scans obtained from a proton transfer mass spectrometer flown over the tropical rainforest of Surinam, J. Atmos. Chem., 38, 133-166, doi:10.1023/a:1006322701523, 2001.

Zimmerman, P. R., Greenberg, J. P., and Westberg, C. E.: Measurements of atmospheric hydrocarbons and biogenic emission fluxes in the Amazon Boundary layer, J. Geophys. Res., 93, 1407, doi:10.1029/JD093iD02p01407, 1988.

Zuidema, P. A., Brienen, R. J. W., and Schöngart, J.: Tropical forest warming: looking backwards for more insights. Trends Ecol. Evol., 27, 193-194, doi:10.1016/j.tree.2011.12.007, 2012. 